$\begin{array}{lll} & \text { International Journal of Educational Studies in Mathematics } \\ \text { WWW.ijesim.com } & \text { ISSN: 2148-5984 }\end{array}$

\title{
Using Computer Supported Collaborative Dynamic Learning Environment in the Instruction of Conics ${ }^{1}$
}

\author{
Türkan Berrin Kağızmanlıa*, Enver Tatar ${ }^{\mathrm{b}}$
}

${ }^{a}$ Giresun University, Education Faculty, Giresun, TURKEY

${ }^{b}$ Atatürk University, Kazım Karabekir Education Faculty, Erzurum, TURKEY

\begin{abstract}
The purpose of this research is to evaluate the applicability of Computer Supported Collaborative Dynamic Learning in the teaching of conics. A qualitative research methodology was used in the study. The sample of the study was composed of a high school mathematics teacher and 26 high school students who were taught by the teacher. The study was carried out in four weeks and the interviews carried out with the teacher and the students. the focus group interviews with students, and the classroom observation form were utilised as data collection tools. The qualitative data obtained from the research were analysed via content analysis and descriptive analysis. As a result of the data analysis, it was found that the behaviours of the teacher and the learning environment were suitable for CSCDL beginning from the first lesson and the behaviours of the students who formed the teams improved to match to the CSCDL environment. Moreover, the students and the teacher thought that learning conics in a CSCDL environment promoted permanent learning, facilitated learning and increased interest in the course. The teacher and the students stated that regarding the dynamic materials and worksheets, the variables were given different values and they helped to visualize the subject and to distinguish the differences between the values. In addition to these, they emphasised that collaborative work fostered collaborative learning. While the students stated that the most important factor which had an effect on learning conics in a CSCDL environment was that they could implement materials as an individual or as a team; the teacher stated that they could see the different values of the variables and the students played an active role in the lesson. Quizzes were conducted, generalizations were made via discussions, and their accuracy was observed. Considering making generalizations, both the teacher and the students emphasized understanding of ellipse, hyperbola, and parabola conceptually.
\end{abstract}

Keywords: computer supported collaborative dynamic learning, GeoGebra, instruction of conics Mathematics, Language and Literacy, International Students.

(c) 2016 IJESIM. All rights reserved

Article History:

Received 09.07.2015 Received in revised form 21.07.2015 Accepted 31.03.2016 Available online 15.06.2016

\section{Extended Abstract}

Integration of dynamic learning in computer supported collaborative learning (CSCL) environments in mathematics teaching is addressed in this study. In this environment students are required to learn different situations and properties in every concept of mathematical expressions including variables. If computer supported collaborative dynamic learning (CSCDL) used in this research study is to be explained, it can be defined as a learning approach which in students are expected to generalize the concepts and definitions using the dynamic mathematics software by creating collaborative teams with teachers guiding them with learning tips. The purpose of this research is to evaluate the applicability of CSCDL in the teaching of conics.

\footnotetext{
1 This study was part of the first author's doctoral dissertation.

${ }^{2}$ Corresponding author's address: Giresun University, Education Faculty, Giresun, Turkey

e-mail: turkanberrin@gmail.com

DOI: http://dx.doi.org/10.17278/ijesim.2016.02.004
} 
A qualitative research methodology was used in this study which was designed as a case study (McMillan and Schumacher, 2010). The sample of the study was composed of a high school mathematics teacher and 26 11th grade high school students who were taught by this teacher. Out of the 26 high school students, 19 of them volunteered to take part in the interviews that were carried out throughout the study. Semi-structured interviews carried out with the teacher and the students (Appendices 1-2-3-4), semistructured focus group interviews (Appendix 5), and classroom observation forms were used as data collection tools. While semi-structured interviews were conducted with three students after teaching each section, semistructured interviews were conducted with five students at the end of the implementation regarding the teaching of the whole unit. At the end of the implementation, semi-structured focus group interviews were conducted with two students from the successful team. All the courses taught to reveal the applicability conditions of CSCDL environment in the teaching of conics were observed from the beginning to the end. Before the implementation process began, an observation form was designed. First of all, a pilot study was carried out in the research study. During the piloting, three topic included in Coordinate Systems taught with CSCD were observed for four course hours. Dynamic materials and worksheets were developed for the teaching of conics with CSCDL. Designing materials and worksheets was based on the topic included in the analytic geometry units of the 11th grade geometry curriculum (MEB, 2010a; MEB, 2010b). It took eight course hours to teach four topics of conics analytic geometry with CSCDL which was included in the Conics unit of the 11th grade geometry course. The teacher of the course determined the students' initial base score (IBS) by calculating the average of three geometry test scores which students took before. Considering each student's IBS, heterogeneous collaborative teams were composed, so a total nine collaborative teams consisting three students each were formed. Each team performed their studies on their computer and worksheets. Before teaching each topic, the teacher occasionally called students' attention by using the materials on an interactive board to introduce the topic to start for the teams' collaborative studies. During the implementation, quizzes on conics were conducted by the teacher. The teacher who evaluated the quizzes determined individual progress scores according to each student's IBS. Taking this into consideration, after completing the CSCD teaching of a topic, each team's score was calculated by taking the average of students' individual progress scores in the team in order to determine the successful team. The teams were congratulated on their success and the most successful team was given gifts and certificates. Observations were conducted for eight course hours using the observation form. The implementations were carried out with the teachers and the students and the first author of the study was present in the class to conduct observations. While both content analysis and descriptive analysis were used for the analysis of data obtained from the semi-structured interviews and semi-structured focus group interviews in the research study, the data obtained from the observations were analysed using descriptive analysis.

The findings obtained from the research were presented under the following sub-titles: "Learning Environment", "Teacher Behaviours", "Team Behaviours", and "Teacher and Students' Views on the Teaching of Conics in a CSCDL Environment". As a result of the data analysis, it was found that the behaviours of the teacher and the learning environment were suitable for CSCDL beginning from the first lesson and the behaviours of the students who formed the teams improved to match the CSCDL environment. The teacher's and students' views regarding the teaching of conics in a CSCDL environment were examined under the following sub-categories: learning conics in a CSCDL environment, dynamic materials, worksheets and collaborative work, factors affecting learning, and generalizations. Moreover, the students and the teacher thought that learning conics in a CSCDL environment promoted permanent learning, facilitated learning and increased interest in the course. The teacher and the students stated that regarding the dynamic materials and worksheets, the variables were given different values and they helped to visualize the subject and to distinguish the differences between the values. In addition to these, they emphasised that collaborative work fostered collaborative learning. While the students stated that the most important factor which had an effect on learning conics in a CSCDL environment was that they could implement materials as an individual or as a team; the teacher stated that the students could see the different values of the variables, the played an active role in the lesson, and generalizations were made via discussions. At the same time, the teacher conducted quizzes and students' understanding was observed. Considering making generalizations, both the teacher and the students emphasized understanding of ellipse, hyperbola, and parabola conceptually. 


\title{
Koniklerin Öğretiminde Bilgisayar Destekli İşbirlikli Dinamik Öğrenme Ortamının Kullanılması
}

\author{
Türkan Berrin Kağızmanlıa , Enver Tatar ${ }^{b}$
}

${ }^{a}$ Giresun Üniversitesi, Eğitim Fakültesi, İlköğretim Bölümü, Giresun, TÜRKIYE

${ }^{b}$ Atatürk Üniversitesi, Kazım Karabekir Eğitim Fakültesi, Erzurum, TÜRKIYY

ÖZ

\begin{abstract}
$\mathrm{Bu}$ araştırmanın amacı bilgisayar destekli işbirlikli dinamik öğrenme ortamının koniklerin öğretimine uygulanabilirliğini değerlendirmektir. Araştırmada nitel araştırma yöntemi kullanılmıştır. Araştırma grubunu bir lise matematik öğretmeni ve bu öğretmenin ders anlattığı sınıftaki 26 lise öğrencisi oluşturmaktadır. Dört haftada gerçekleştirilen bu araştırmada veri toplama aracı olarak; öğretmen ve öğrencilerle yapılan mülakat, öğrencilerle yapılan odak grup mülakatı ve sınıf içi gözlem formu kullanılmıştır. Araştırmadan elde edilen nitel verilerin analizinde içerik analizi ve betimsel analiz kullanılmıştır. Verilerin analizi sonucunda; ders öğretmeninin davranışlarının ve öğrenme ortamının ilk dersten itibaren BDIDÖ ortamına uygun olduğu, takımları oluşturan öğrencilerin davranışlarının ise BDİDÖ ortamına uygun olacak şekilde geliştiği elde edilmiştir. BDİDÖ ortamında konikleri öğrenme hakkında, öğrencilerin ve ders öğretmeninin kalıcı ve kolay öğrenmeyi sağladığını ve derse olan ilgiyi artırdığını düşündükleri belirlenmiştir. Öğretmen ve öğrenciler dinamik materyal ve çalışma yaprakları hakkında, değişkenlere farklı değerler verildiğini, konuyu görselleştirmeyi ve değerler arasındaki farkları ayırt etmeyi sağladığını belirtirmişlerdir. İşbirlikli çalışma hakkında ise birlikte öğrenmeyi sağladığı üzerinde durdukları görülmüştür. BDİDÖ ortamında konikleri öğrenmeyi etkileyen en önemli faktörü, öğrenciler, bireysel veya takım halinde materyalleri uygulayabilme olarak ifade ederken; ders öğretmeni, değişkenlerin farklı değerlerini görebilme, öğrencilerin derste aktif rol oynaması, izleme testlerinin yapılması, genellemelere tartışarak varabilme ve doğruluğunu gözlemleyebilme şeklinde belirtmiştir. Genellemelere varma hakkında ise ders öğretmeni ve öğrencilerin elips, hiperbol ve parabolü kavramsal olarak anlayabilme üzerinde durdukları görülmüştür.
\end{abstract}

Anahtar Kelimeler: Bilgisayar destekli işbirlikli dinamik öğrenme, GeoGebra, koniklerin öğretimi

(C) 2016 IJESIM. Tüm hakları saklıdır.

Makale Tarihçesi:

Alındı 09.07.2015 Düzeltilmiş hali alındı 21.07.2015 Kabul edildi 31.03.2016 Çevrimiçi yayınlandı 15.06.2016

\section{Giriş}

Bilgisayar destekli işbirlikli öğrenme (BDïÖ), günümüzde işbirlikli öğrenme ile bilgisayarın ve bilgisayara bağlı teknolojiler olan internet (Stahl, Koschmann ve Suthers, 2006) veya birçok farklı alt yapı ve amaçla oluşturulan yazılımların öğrenme ortamında bir arada kullanılmasıyla ortaya çıkmıştır. Lipponen, Rahikainen, Lallimo ve Hakkarainen (2003) işbirlikli öğrenmenin bilgisayarlar tarafından desteklendiğini ve işbirlikli öğrenme gruplarını oluşturan öğrencilerin bilgisayar yoluyla etkileşimli çalışarak nasıl daha iyi öğrenebilecekleri sorusunun BDİ̈̈' yi beraberinde getirdiğini belirtmektedir.

Açıkgöz (1992), bir grup çalışmasının işbirlikli öğrenme olabilmesi için sağlanması gereken koşulları şu şekilde sentezlemiştir: Olumlu bağımlılık, grup ödülü/ortak ürün, bireysel değerlendirilebilirlik, yüz yüze (destekleyici) etkileşim, sosyal beceriler, grup sürecinin değerlendirilmesi ve eşit başarı fırsatı. Öğrenci açısından bakıldığında grup-takım oluşturma beraberinde bazı problemleri de getirmektedir. Bu problemleri etkileşimde bulunmada yaşanılan zorluklar, motivasyon sağlamada yaşadıkları zorluklar ve ihtiyaç duyulan eğitimsel araçların temini olarak sıralanabilir (Ching Sing, Wei Ying, Hyo-Jeong ve Horn Mun, 2011). Bu noktada öğretmenlerin ve grupların bir arada etkileşimli çalışması ve öğrenme ürünlerine kolaylıkla ulaşmalarını sağlayacak teknolojik alt yapının sağlanması gerekmektedir.

BDİÖ, öğrencilerden oluşan grup üyelerinin birbirlerinin öğrenmelerini etkili olarak desteklemek için öğrenme araçları geliştirmeyi ve öğrencilerin kavramlar arasındaki ilişkilerin farkında olmasını amaçlamaktadır (Buder, 2011). ChingSing ve diğerleri (2011) öğretmenin eğitimsel ve pedagojik becerilerinin, öğrenme ortamının oluşturulması, etkinliklerin yürütülmesi ve öğrencilerin etkileşimde bulunmasında

Sorumlu yazarın adresi: Giresun Üniversitesi, Eğitim Fakültesi, İlköğretim Bölümü, Giresun, TÜRKIYE.

e-posta: turkanberrin@gmail.com 
önemli bir rol oynadığını belirtmektedirler. Buna göre öğretmenler, öğrencilerin kimlerle ve hangi eğitimsel araçla çalışmak istedikleri ile ilgili olarak öğrencileri desteklemelidirler. Bu durum öğrencilerin daha dinamik olarak etkileşimde bulunmalarını sağlayacak ve onlara sorumluluk verecek, bu sayede topluluklar arasında bilgi oluşturabilmeyi öğreneceklerdir (ChingSing vd., 2011). Böylece işbirlikli öğrenme, öğrencilerin küçük takımlar halinde ve ortak bir amaç doğrultusunda, birbirlerinin öğrenmelerinden sorumlu oldukları bir öğrenim süreci olacaktır (Açıköz, 1992; Slavin 1980).

İşbirlikli öğrenme teknikleri arasında gösterilen ve matematik öğretimine uygulanabilirliği (Slavin, 1990; Slavin, 1994) olan öğrenci takımları başarı bölümleri tekniği (ÖTBB) Slavin (1990) tarafından geliştirilmiştir. Bu teknik, işbirlikli öğrenme içerisinde olan diğer tekniklerde de olduğu gibi akademik kavramları öğrenmek için öğrencilerin işbirlikli öğrenme takımları içerisinde birlikte çalışmaları ve kendi öğrenmeleri yanı sıra takım arkadaşlarının da öğrenmelerinden sorumlu olmaları düşüncesine dayanmaktadır (Slavin, 1994). Bu açıdan değerlendirildiğinde, bu tekniğin takımlar, sunum, sınavlar, bireysel ilerleme puanları ve takım ödülü olmak üzere beş öğesi vardır. Bu teknikte öncelikle, öğrenciler başarı düzeyi, cinsiyet ve ırk açısından üç, dört veya beş kişilik heterojen gruplara ayrılır. Öğretmen konuyu görsel ve işitsel materyallerle öğrencilere sunar. Daha sonra öğrenciler takım olarak çalışma yaprakları gibi öğrenme malzemeleri üzerinde çalışırlar ve birbirlerinin öğrenmelerine destek olurlar. Öğrenciler belirli periyodlarla bireysel olarak sinava girerler. İzleme testleri olarak bilinen bu sınavlarda takım üyelerinin birbirlerine yardım etmesi söz konusu değildir. Takımdaki her öğrencinin bireysel ilerleme puanı belirlenir. Öğrenci için ulaşacağı bir amaç saptanarak önceki sınavına göre daha iyi bir başarı gösterirse puan alması söz konusu olur. Takım puanları her takımdaki öğrencilerin gelişme puanlarının ortalaması alınarak elde edilir. Böylece öğrenci kendisiyle yarışmış olur. Takım puanı belirli ölçütlere göre karşılaştırılarak takımlara takım ödülü adı altında çeşitli pekiştireçler verilir (Açıkgöz, 2003).

İşbirlikli öğrenme faaliyetlerinde öğretmenler yol gösterici durumundadırlar. Bunun için işbirlikli öğrenme okul sınırları içinde uygulandığında dersleri işbirliği ile nasıl kavramsal bir sisteme dönüştürecekleri ve öğrencilerini işbirlikli öğrenmeye adapte etme konusunda uzman olmalıdırlar (Ilgar ve Babacan, 2012). Öğretmenlerin bilgisayar ve bilgisayar teknolojilerini derslerine entegre etmeleri, öğrencilerin ise öğrenme etkinliklerini sınıf ortamında işbirliği içerisinde gerçekleştirmeleri, amacına uygun olarak hazırlanmış öğrenme ortamları ile mümkün olur. İlerleme kaydedilmesine rağmen, öğrenmeyi desteklemek ve sınıf ortamında işbirliği sağlamak için BDİÖ sınıflarındaki eğitim ve öğretim programının sıraya konması ve bu sınıflarda ele alınan yaklaşımlar ile ilgili sorunlar bulunmaktadır (Lee, Chan ve Aalst, 2006). Böyle öğrenme ortamlarında eğitimsel içeriğin nasıl anlaşılması gerektiği ve kullanılacak analitik yapının tanımlanması için uygulanan yaklaşımlar arasında tartışmalar bulunmaktadır (Arnseth ve Ludvigsen, 2006). Alan yazın incelendiğinde BDIÖ’ nin internet ortamında senkronize olmuş işbirlikli takımların bir arada çalışmalarının incelendiği araştırmalara daha çok rastlamak mümkün iken BDİÖ' nin gerçek sınıf ortamında oluşturulan işbirlikli çalışmaları daha az karşımıza çıkmaktadır. Bununla birlikte işbirlikli çalışmalar sırasında uygulanan bilgisayar destekli yapının matematik eğitiminde nasıl ele alındığı öğrenci ve öğretmenlerin bu öğrenme şeklini benimsemeleri açısından önem arz etmektedir. Matematik eğitiminde BDİÖ ele alınıp, matematiksel ifadelerin değişken içerdiği ve öğrencilerin her kavram içerisinde farklı durum ve özellikleri öğrenmeleri gerektiği düşünüldüğünde BDİÖ ortamlarında dinamik öğrenmenin entegre edilmesi söz konusu olmaktadır. Güven ve Karataş' a (2009) göre aynı özellikteki noktalar kümesini oluşturan yer problemlerinin geleneksel ortamlarda görselleştirilmesi son derece zordur ve çözüm sürecinde sezgiler ön plana çıkmaktadır. Buna göre sorulan geometrik yer, önce uygun çizim yöntemleri ile çizilmelidir. Geometrik yer problemlerinde neredeyse her bir soru için farklı bir şekil tasarlamak gerekmektedir. Örneğin, iki noktadan eşit uzaklıktaki noktaların geometrik yerini bulurken elips çizebilen, bir doğru ve noktaya eşit uzaklıktaki noktaların geometrik yerini bulurken parabol çizen bir aracın geliştirilmesi gerekmekte, her bir soru için bu şekilde araçlar tasarlamak ise geleneksel ortamlarda oldukça zor olmaktadır (Güven ve Karataş, 2009). Buna göre bu araştırmada ortaya koyulan bilgisayar destekli işbirlikli dinamik öğrenme (BDIDÖ) açıklanmak istenirse; öğrencilerin işbirlikli takımlar oluşturularak bilgisayarlar üzerinde kullandıkları dinamik matematik yazılımı sayesinde kendilerinden beklenen tanım ve kavramların genellemelerine vardıkları, öğretmenlerinin ise onlara ipuçlarıyla rehberlik ettiği öğrenme yöntemi olarak tanımlanabilir. Analitik geometrinin, koordinat yönteminde genellemeler, konik denklemleri ve eğrilerinin izlenmesi, doğru, nokta ve düzlem üzerinde temel problemlerin çözümünü içerdiği (Boyer, 1956) düşünüldüğünde; koniklerin öğretiminin analitik geometri öğretimi için esas teşkil ettiği söylenebilir. Dairesel koninin bir düzlem ile kesişiminden elde edilen eğriler 
konikleri meydana getirmektedir. Bu eğriler çember, elips, hiperbol ve parabol olarak adlandırılmakta ve cebirsel olarak açıklanabilmektedir (Sullivan, 2008). Eğrilerin cebirsel olarak ifade edilebilmesinin geometrik yer problemlerine işaret ettiği göz önüne alındığında koniklerin öğretimi öğrenciler için öğrenilmesi zor olabilecek konular arasında yer alabilmekte, ezberlenmesi gereken formüller yığını olarak görülmesine sebep olmaktadır. Bir eğrinin parametrik denklemi dikkatli bir şekilde öğretildiğinde yer problemleri de kolaylıkla çözülebilecektir (Young, 1909). İşbirlikli ve dinamik öğrenmenin her ikisinin bir arada olduğu öğrenme ortamının koniklerin öğretimini nasıl etkileyeceği durumu karşımıza çıkmaktadır. Matematik öğretmeninin BDİDÖ ortamını koniklerin öğretiminde derslerine entegre etme sürecinin incelemesi ve konik öğretiminde uygulanan bu öğrenme ortamının olumlu ve olumsuz özelliklerinin, matematik öğretimine kattığı boyutun araştırma süreci boyunca öğretmen ve öğrencilerin görüşlerine göre değerlendirilmesi ve böylelikle konik öğretiminde uygulanabilir bir içeriğin tanımlanması alan yazına katkıda bulunması açısından önem arz etmektedir. $\mathrm{Bu}$ araştırmanın amacı BDİDÖ ortamının koniklerin öğretimine uygulanabilirliğini değerlendirmektir.

\section{Yöntem}

\section{Araștırma Yöntemi}

Nitel araştırma yönteminin kullanıldığı bu araştırma durum çalışması olarak desenlenmiştir (McMillan ve Schumacher, 2010). Durum çalışması sınırlandırılmış bir sistemi veya bir durumu zaman içerisinde ortamda bulunan birçok veri kaynağını kullanarak inceler (McMillan ve Schumacher, 2010).Ele alınan durum, bir program, bir olay, bir aktivite veya zaman ve mekanla sınırlandırılmış bireyler olabilir ve araştırmacı bu durumu ve sınırlılıklarını açıklar (Creswell, 2011; McMillan ve Schumacher, 2010).

\section{Araştırma Grubu}

Araştırma grubunu bir lise matematik öğretmeni ve bu öğretmenin ders anlattığı sinıftaki 26 on birinci sınıf lise öğrencisi oluşturmaktadır. Araştırma süresince bu öğrenciler arasından gönüllü 19 öğrenci ile mülakatlar gerçekleştirilmiştir. Ders öğretmeni, bu çalışmanın yazarları tarafından daha önce yapılan hizmetiçi eğitim seminerinde dinamik matematik yazılımı GeoGebra' yı ve BDİDÖ’ i öğrenmişken, öğrenciler yazılım hakkında herhangi bir ön bilgiye sahip değildir.

\section{Veri Toplama Araçları}

Araştırmada veri toplama aracı olarak, öğretmen ve öğrencilerle yapılan yarı yapılandırılmış mülakatlar (Ek 1-2-3-4), yarı yapılandırılmış odak grup mülakatı (Ek-5) ve sınıf içi gözlem formu kullanılmıştır.

Araştırmaya katılan öğretmen ve öğrencilerin koniklerin öğretildiği BDİDÖ ortamına ilişkin görüşlerini belirleyebilmek için öğretmen ve öğrenciler ile yarı yapılandırılmış mülakatlar yapılmıştır. Her kazanımın öğretiminin hemen ardından üçer öğrenci ile yarı yapılandırılmış mülakat gerçekleştirilirken, ünitenin tamamının öğretimine ilişkin ise uygulamanın sonunda 5 öğrenci ile yarı yapılandırılmış mülakat gerçekleştirilmiştir. Ayrıca, uygulama sonunda işbirlikli dinamik öğrenme takımları arasında başarılı olan takımın görüşlerini ve deneyimlerini belirleyebilmek üzere 2 öğrenci ile yarı yapılandırılmış odak grup mülakatı yapılmıştır. Yarı yapılandırılmış mülakat soruları alan yazın taraması yapılarak ve araştırmanın problem durumu göz önünde bulundurularak hazırlanmışır. Taslak sorular, alan eğitiminde 2, eğitim alanında 1 uzman görüşüne sunulmuş, alınan dönütler doğrultusunda yeniden düzenlenmiştir. Bu sorular düzenlendikten sonra alan eğitiminde uzman araştırmacıya yeniden kontrol ettirilerek pilot araştırmada kullanılmıştır. Pilot mülakatlar ses kayıt cihazıyla kaydedilmiştir. Mülakatlar sırasında öğretmen ve öğrencilerin anlamakta ve anlamlandırmakta zorluk yaşadıkları sorular ve elde edilen veriler göz önüne alınarak mülakat soruları yeniden düzenlenmiştir. Sorular sondalarla desteklenerek, görüşülen bireyin soruyu daha iyi anlamasına yardımcı olma ve ayrıntılı yanıtlar verilmesi sağlanmıştır (Yıldırım ve Şimşek, 2008). Soruların son şekli oluşturularak araştırmanın odağında bulunan ünitenin uygulama verilerinin elde edilmesinde kullanılmıştır. Uygulamalar sırasında yapılan gözlemlere dayanarak kazanımın o derste öğretimiyle ilgili belirlenen durumlar varsa mülakat sırasında soru olarak yöneltilmiştir. Buna göre uygulaması yapılan ünitelerde yer alan her kazanımın öğretimine ilişkin öğrenci ve öğretmen elde edilen mülakat verileri, uygulamalar sırasında elde edilen gözlem verileri ile birleştirilerek BDİDÖ ortamının uygulanabilirlik şartlarının bir bütün halinde ortaya koyulabilmesi için kullanılmıştır. 
Araştırmada koniklerin öğretiminde BDİDÖ ortamının uygulanabilirlik şartlarını ortaya koyabilmek için yapılan tüm dersler başından sonuna kadar gözlemlenmiştir. Uygulama süreci başlamadan önce gözlem formu oluşturulmuştur. Öncelikle gözlemlenmesi planlanan BDİDÖ ortamının özelliklerinin genel anlamda hangi önemli durumlarda şekilleneceği ilgili alan yazın göz önünde bulundurularak belirlenmeye çalışılmıştır. Daha sonra mevcut alan yazın ve Matematik Dersi 9. -12. Sınıflar Öğretim Programı (Milli Eğitim Bakanlı̆̆1 [MEB], 2013a) incelenmiştir.

Taslak form, alan eğitiminde 2, eğitim alanında uzman 1 araştırmacıya sunulmuştur. Form, alınan dönütler doğrultusunda yeniden düzenlendikten sonra alan eğitiminde uzman araştırmacıya kontrol ettirilerek pilot araştırmada kullanılmıştır. Pilot araştırmada BDİDÖ ortamında gerçekleştirilen Koordinat Sistemleri ünitesinde yer alan 3 kazanımın, 4 ders saati boyunca gözlemi yapılmıştır. Öğrencilerin bilgisayar destekli ve işbirlikli öğrenmeyi kendi aralarında nasıl oluşturdukları ve üzerinde durdukları durumlar belirlenmeye çalışılmıştır. Bu sayede hem gözlem formunda bulunan mevcut durumlar hem de oluşabilecek başka durumlar gözlemlenmeye ve buna göre de formun geliştirilmesine çalışılmıştır. Her kazanıma ait gözlemlenen veriler forma kaydetmiştir. Pilot araştırmada yapılan dersler boyunca gözlem formu güncellenerek son hali oluşturulmuştur. Gözlem formu 9 kategori altında yer alan ve her biri bir davranışı gösteren 34 koddan oluşmuştur. "Öğretmenin rolü" , "takım ödülü/ortak ödül”, "olumlu bağımlılık", "bireysel değerlendirilebilirlik", "yüz yüze (destekleyici) etkileşim”, "sosyal beceriler", “değerlendirme”, "eşit başarı fırsatı" ve "öğrenme ortamı" formda yer alan kategorilerdir. Kategoriler oluşturulurken bir grup çalışmasının işbirlikli öğrenme olabilmesi için belirtilen bu özelliklerin olması gerektiği (Açıköz, 1992) göz önüne alınmıştır. Kodların oluşturulmasında ise hem ilgili kategori altında olması gereken özellikler hem de dinamik öğrenme özellikleri birleştirilmeye ve bu sayede işbirlikli dinamik öğrenmeye örnek teşkil edecek kodlar/davranışlar oluşturulmaya çalışılmıştır.

Formun son hali araştırmanın odağında bulunan ünitenin BDİDÖ ortamının gözlemlenmesinde kullanılmıştır. Buna göre, Konikler ünitesinde yer alan 4 kazanımın 8 ders saati boyunca gözlemleri yapılarak gözlem formuna ilgili derste not edilmiştir.

\section{Dinamik Materyal ve Çalışma Yapraklarının Geliştirilmesi}

Koniklerin BDİOÖ ortamında öğretimi için dinamik materyaller ve çalışma yaprakları geliştirilmiştir. Hazırlanan materyaller çalışma yapraklarıyla kullanılarak, hem dinamik öğrenme ortamı için gerekli olan farklı örnek durumları ortaya koyabilme ve öğrencinin kendi öğrenmelerini gerçekleştirebilmesi unsurlarını hem de işbirlikli öğrenme için gerekli olan birlikte öğrenebilmeyi sağlayan bir çalışma nesnesinin olması unsurunu bir araya getirmek amaçlanmıştır.

Uygulama süreci başlamadan önce hazırlanan materyaller, dinamik ve elektronik çalışma sayfaları olarak tanımlanabilir. Materyallerin dinamik olması herhangi bir değişkene farklı değerler verebilme, nesneleri hareket ettirme ve meydana gelen değişimleri gözlemleyebilmeyi sağlamaktadır. Dinamik materyaller uygulama sürecinde, öğrencilerin takımlar halinde kendi bilgisayarlarında, öğretmenlerin ise etkileşimli tahta üzerinde kullanmaları amacıyla hazırlanmıştır. Materyaller GeoGebra yazılımı kullanılarak oluşturulmuştur. 11. sınıf geometri öğretim programında (MEB, 2010a; MEB, 2010b) analitik geometri ünitelerinde yer alan kazanımlar materyallerin hazırlanmasında temel alınmıştır. Materyaller oluşturulurken öncelikle, her kazanımın dinamik öğrenme ortamında nasıl öğretileceği araştııılmıştır. Kazanımların içerdiği kavramların dinamik öğretimini sağlayarak öğrencilerin kavramları keşfetmesine imkan vermek hedeflenmiştir.

Her bir kazanımın öğretiminde materyallerin işbirlikli dinamik öğrenme ortamında kullanılabilmesi için hazırlanan çalışma yapraklarının öğrencilerin işbirlikli olarak dinamik öğrenmelerini sağlayacak şekilde olmasına dikkat edilmiştir. Buna göre, çalışma yapraklarında belirli yönergeler verilmiş ve öğrencilerin takım halinde bu yönergeleri uygulamaları istenmiştir. Çalışma yapraklarında bulunan soruların kısa ve anlaşılır olmasına dikkat edilmiştir. Bir kavramın öğretiminde kavrama ait olabilecek bütün durumlar çalışma yapraklarında örnek olarak verilmiş ve öğrencilerden bu durumları dinamik materyal üzerinde uygulayarak sonuç ve genellemelere varmaları beklenmiştir. Hazırlanan çalışma yaprakları öğrencilerin kavramları matematiksel ifadelerle anlamlandırabilmelerinde yol gösterici durumdadır. Çalışma yapraklarında yer alan ifadelerin, öğrencilerin takım içinde işbirlikli çalışmalarına imkân sağlayacak ve birbirlerinin öğrenmelerini 
sorgulayacak şekilde olmasına dikkat edilmiştir. Tablo 1' de öğretimi yapılan Konikler ünitesinin kazanımları verilmiştir.

Tablo 1. Araştırmada Öğretimi Yapılan Ünite ve Kazanımları

\begin{tabular}{|c|c|}
\hline Üniteler & Kazanımlar \\
\hline \multirow[t]{4}{*}{ Konikler } & 1. Koniği, koniğin temel elemanlarını açıklar ve konikleri sınıflandırır. \\
\hline & 2. Elipsi açıklar ve standart denklemini elde eder. \\
\hline & 3. Hiperbolü açıklar ve standart denklemini elde eder. \\
\hline & 4. Parabolü açıklar ve standart denklemini elde eder. \\
\hline
\end{tabular}

Tablo 1' de verilen kazanımların BDİD öğretimi, öğrencilerin takım halinde çalışmalarını sağlayan dinamik materyal ve çalışma yapraklarıyla gerçekleştirilmiştir. Materyal ve çalışma yaprakları oluşturulurken alan yazın incelenmiş ve ilgili kitaplar (Beecher, Penna ve Bittinger, 2007; Boyd, Cummins, Malloy, Carter ve Flores, 2008; Burger, vd, 2008; Çelik, 2013; Hungerford ve Shaw, 2009; Larson, Boswell, Kanold ve Stiff, 2004; Lial, Hornsby ve McGinnis, 2012; MEB, 2013a; MEB, 2013b; Sullivan, 2008; Timmons, Johnson ve McCook, 2010), GeoGebra resmi sitesinde (www.geogebra.org) yer alan ve açık kullanıma sahip dinamik materyaller, çeşitli matematik eğitimi siteleri (www.mathopenref.com, www.mathsisfun.com/geometry) ile koniklerin inşasına yer veren videolardan (www.youtube.com) faydalanılmıştır.

Hazırlanan materyal ve çalışma yaprakları alan eğitiminde uzman bir araştırmacıya bilgisayar üzerinde sunularak alınan geri dönütlerle düzeltmeleri yapılmıştır. Ayrıca ünitelerin öğretiminden önce dersin öğretmeni ile birlikte materyal ve çalışma yaprakları üzerinde birlikte çalışılarak gerekli görülen yerlerde düzenlemeler yapılmıştır. Bu materyallerden birine ait ekran görüntüleri Şekil 1'de verilmiş ve materyal ile birlikte kullanılan çalışma yaprağı da aşağıda örnek olarak sunulmuştur.
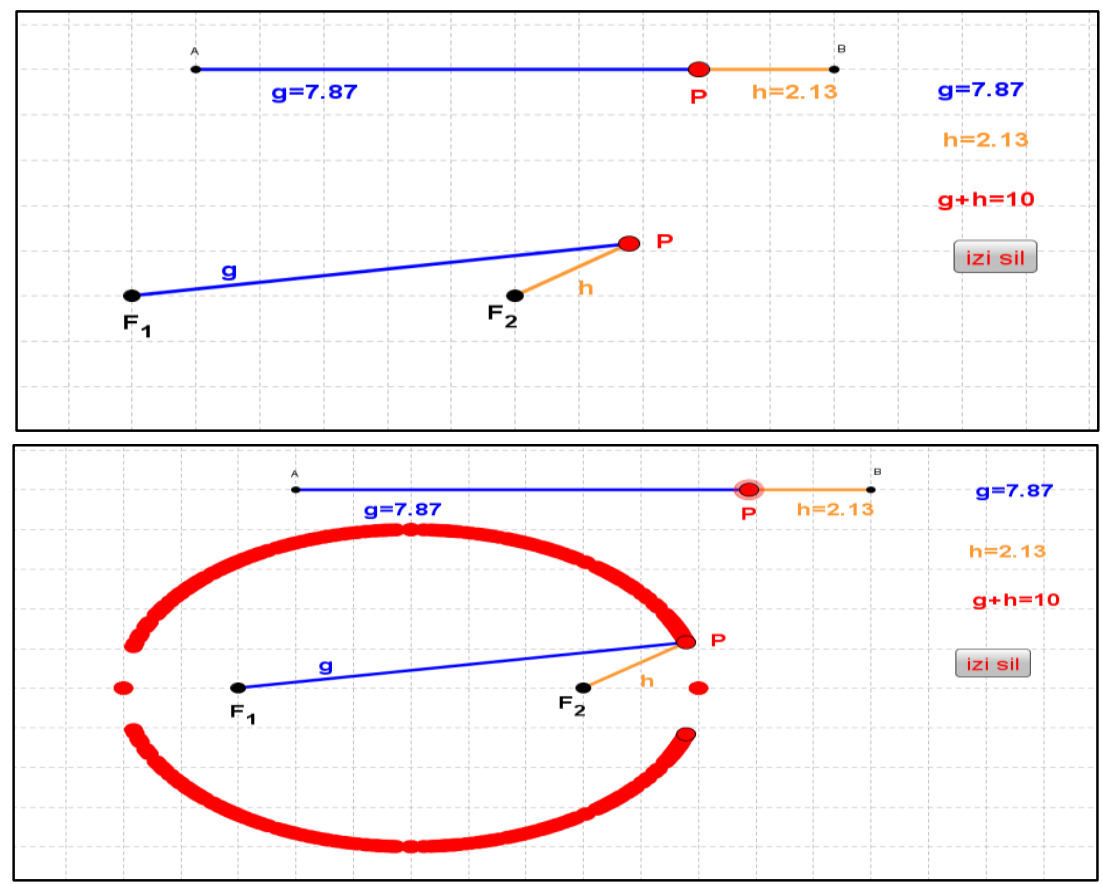

Şekil 1. Elips oluşumu a materyalinin farklı görüntüleri

Şekil 1' de gösterilen dinamik materyal, elipsin oluşumunun gösteriminde ve elipsin geometrik yerini açıklamak amacıyla kullanılabilmektedir. Ayrıca bu materyal ile birlikte odak noktaları ve elipsin merkezi gibi kavramların anlaşılması sağlanabilmektedir. Takımların bu materyal ile birlikte aşağıda verilen ilgili çalışma yaprağını kullanmaları ve kendi aralarında birlikte düşünüp ortak bir kararla genellemelere ulaşmaları beklenmektedir. 
Çalışma yaprağının içeriği;

Takım arkadaşlarınızın her birinin konuyu öğrendiğ̈inden emin olunuz.

Öğretmeninizden yardım alabilirsiniz.

Masa üstünde kayıtlı olan elips oluşumu a.ggb dosyasını açınız.

Ekranda bulunan $A B$ doğru parçasını gözlemleyiniz. AB doğru parçası üzerindeki $P$ noktasını sürükleyiniz. $P$ noktasının doğru parçası üzerinde ayırdı̆̆ı parçaların g ve h olduğu görülmektedir. Buna göre aşă̆ıdaki adımları takip ediniz:

Ekranda görülen sabit iki nokta $F_{1}$ ve $F_{2}$ olmak üzere, $P$ noktasını sürükleyerek $F_{1} P=g$ ve $F_{2} P=h$ uzaklikların gözlemleyiniz. Elde ettiğiniz farkh gözlem sonuçlarını aşağıdaki tabloya not ediniz.

\begin{tabular}{|c|c|c|c|}
\hline \multirow{4}{*}{ 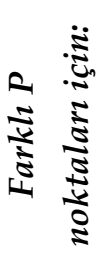 } & $F_{1} P=g$ & $F_{2} P=h$ & $g+h$ \\
\hline & & & \\
\hline & & & \\
\hline & & & \\
\hline
\end{tabular}

Doğru parçası üzerinde P noktasını sürüklediğinizde $g$, $h$ ve $g^{+h}$ için gözlemleriniz nelerdir? Bir genellemeye varabilir misiniz?

P noktasını sürükleyiniz. P noktasının sabit iki nokta $F_{1}$ ve $F_{2}$ ye uzaklikları arasında nasıl bir ilişki oluşmaktadır?

P noktası değiştikçe; oluşan noktaların ortak özelliği ne olabilir? Hangi geometrik şeklin oluştuğunu belirtiniz?

Sabit olan iki nokta olmak üzere bu noktalara elipsin odak noktaları denir.

Öğrencilerin P noktasının farklı yerlerdeki konumu için F1P ve F2P uzaklıklarını görmeleri istenmiştir. Bu sayede sabit iki noktaya uzaklıkları toplamı sabit olan noktaların özelliklerini anlamaları ve bu noktaların geometrik yerinin tanımını yapabilmeleri hedeflenmiştir.

\section{Veri Toplama Süreci}

Araştırmada 11. sınıf geometri dersi Konikler ünitesinin koniklerin analitiğini içeren 4 kazanımının BDIDÖ ile öğretimi 8 ders saatinde yapılmıştır. 4 haftada gerçekleştirilen uygulama, ders öğretmeni ve 26 lise öğrencisi ile gerçekleştirilmiştir. Uygulamaya başlamadan önceki hafta içinde dersin öğretmeni ile bir araya gelinmiş ve araştırmanın metodolojisi hakkında çalışmalar yapılmıştır. Ders öğretmeni, öğrencilere daha önce uygulanan 3 geometri yazılı notlarının ortalamasını alarak öğrencilerin Başarı Puanlarını (BP) belirlemiştir. Buna göre her öğrencinin BP na göre heterojen durumda olan işbirlikli takımları oluşturmuştur. Buna göre 3 kişilik toplam 9 işbirlikli takım meydana gelmiştir. Öğretmen takımları oluştururken öncelikle öğrencileri BP larının büyüklüğüne göre sıralamıştır. Takımları 1, 2,..,9 ile numaralandırmış ve başarı puanı en fazla olan ilk 9 öğrenciyi sırasıyla 1., 2.,...,9. takımlara yerleştirmiştir. Daha sonra BP listesinde sıralanan ikinci 9 öğrenciyi sırasıyla 9., 8.,...,1. takımlara yerleştirirken BP listesinin sonunda kalan 8 öğrenciyi ise sırasıyla 1., 2.,...,8. takımlara yerleştirmiştir. Uygulamaya başlamadan önceki hafta, takım çalışması hakkında bilgilendirilmesi için öğrencilere BDIDÖ takım çalışmasının anlatıldığı bir kitapçık verilmiştir. Öğrencilerden takım adı, takım rengi ve takım amblemi konusunda karara varmaları istenilmiştir. Dersin uygulamaya başlamasından önce ise uygulamanın yapılacağı laboratuvara BDİÖ ortamını anlatan poster asılmış, bilgisayarlara ve etkileşimli tahtaya GeoGebra yazılımı kurulmuştur. Ayrıca her hafta uygulamadan önce kazanımla ilgili olan materyaller bilgisayarlara yüklenmiştir. Uygulama süresince her hafta ders öğretmeni ile bir araya gelinerek kazanımların öğretiminde kullanılacak dinamik materyaller ve çalışma yaprakları öğretmenle birlikte gözden geçirilmiştir. 
Her takım kendi bilgisayarı ve çalışma yaprağı üzerinde çalışmalar gerçekleştirmiştir. Dersin öğretmeni her kazanımın öğretiminden önce kazanımın gerektirdiği hazır bulunuşluk durumlarını göz önünde bulundurarak öğrencilere etkileşimli tahta üzerinde zaman zaman materyalleri kullanarak hatırlatma yapmış ve takımların işbirlikli çalışmalarını başlatmıştır. Her dersin ardından öğretmen tarafından kontrol etmek ve geri dönütte bulunmak üzere takımların çalışma yaprakları toplanmıştır. Bu çalışma yapraklarının fotokopileri çekilerek araştırmada kullanmak üzere asıl nüshaları alınmış, fotokopiler üzerinde ise incelemeler yapılarak takip eden bir sonraki gün takımlara çalışma yaprakları geri verilmiştir. Bu yolla takımlara aldıkları geri dönütler sayesinde yeniden değerlendirme imkanı sunulmak istenmiştir. Uygulamalar sırasında kazanımlarla ilgili izleme testleri yapılmıştır. İzleme testlerine öğrenciler bireysel olarak katılmışlardır. Bu testler, ilgili ders kitapları (MEB, 2010b; Çelik, 2013) incelenerek hazırlanmıştır. İzleme testlerinin uygunluğu dersin öğretmeni tarafından incelenmiştir. Testlerin her biri 15 dakikada tamamlanmıştır. İzleme testlerinin değerlendirmesini yapan ders öğretmeni her öğrencinin BP na göre bireysel ilerleme puanın belirlemiştir. Bireysel ilerleme puanı şu şekilde belirlenmiştir: İzleme testinin sonucu BP dan; 10 puan düşük ise 0, 1-10 puan düşük ise 10,1-10 puan fazla ise 20, 10 ve üstü puan fazla ise 30 puan verilmiştir. Buna göre kazanımların BDİD öğretiminin tamamlanmasının ardından takımdaki öğrencilerin bireysel ilerleme puanlarının ortalaması alınarak her takımın puanı hesaplanmış ve başarılı takım belirlenmiştir. Takımlar başarılarından dolayı sınıfta tebrik edilmiş ve en başarılı takıma hediye ve sertifika verilmiştir. Her kazanımın BDIDÖ ile öğretiminin hemen ardından öğretmen ve 3 öğrenci ile yarı yapılandırılmış mülakatlar gerçekleştirilmiştir. Öğrencilerle yapılan mülakatlar ortalama 6 dakika, öğretmen ile yapılan mülakatlar ortalama 14 dakika sürmüştür. Kazanımların tamamının BDİDÖ ile öğretiminin ardından ise, 5 öğrenci ile yapılan mülakatlar ortalama 16 dakika sürerken öğretmen ile yapılan mülakat 21 dakika sürmüştür. Başarılı takımla gerçekleştirilen odak grup mülakatı ise 26 dakika sürmüştür. Mülakatlar sırasında ses kayıt cihazı kullanılması konusunda öğretmen ve öğrencilerden izin alınmıştır. Gözlem formu kullanılarak 8 ders saati gözlem yapılmıştır. Uygulamaları öğretmen ve öğrenciler gerçekleştirmiş, çalışmanın birinci yazarı sadece gözlem yapmak için öğrenme ortamında bulunmuştur.

\section{Verilerin Analizi}

Araştırmada yarı yapılandırılmış mülakat ve yarı yapılandırılmış odak grup mülakatlarından elde edilen verilerin hem içerik analizi hem de betimsel analizi yapılırken gözlemlerden elde edilen verilerin analizinde betimsel analiz yapılmıştır.

Araştırmada öncelikle, öğretmen ve öğrencilerle yapılan yarı yapılandırılmış mülakatlar transkript edilmiştir. Elde edilen ham verilerin içerik analizi için, veriler okunmuştur ve ilk kategoriler altında kodlar ortaya çıkarılmıştır. Daha sonra elde edilen verilerin iç güvenirliği için tutarlık incelemesi yapılarak, veriler tekrar okunup kodlanmıştır. Bu işlem birkaç kez tekrar etmiş ve kodlar düzenlenmiştir. Kategoriler altında tanımlanan ve bulunan bu kodlar sunulmuştur. Katılımcılardan örnek alıntılar yapılarak tanımlanan kodların anlaşılması sağlanmıştır.

Gözlem verileri, araştırmanın uygulamasından önce oluşturulan gözlem formuna göre her kazanımın BDİDÖ ile derste öğretimi sırasında elde edilmiştir. Buna göre veriler, gözlem formunda bulunankategoriler altında analiz edilmiştir. Tanımlanan kategoriler altında yer alan her bir kod için "Gözlenme Durumu Kodlamaları" ders esnasında gözlemlenmiştir. Buna göre, " 0 " değeri tanımlanan davranış sınıf ortamında gerçekleştirilmediğinde, "1" değeri tanımlanan davranış yüzeysel olarak gerçekleştirildiğinde ve "2" değeri ise tanımlanan davranış BDIDÖ ortamına uygun olarak gerçekleştirildiğinde verilmiştir. Her bir kod içinde tanımlanan davranışlar, takımlar için ayrı ayrı gözlemlenmiştir ve her takımın gözlem durumu belli olmuştur. Elde edilen gözlem durumları her davranış içinde toplanarak takım sayısına bölünmüştür. Bu şekilde her bir kod için, sınıfta gözlemlenen ve her takımın değerlendirildiği bir gözlem durumu belirlenmiştir. Buna göre veriler, "Gözlenme Durumu Kodlamaları" nda yer alan " 0 ", " 1 " ve " 2 " değerlerinin tanımladığ duruma göre yorumlanmıştır. Her iki saatlik dersi gözlemlemek için bir gözlem formu kullanılmıştır. Bu sebeple bir kazanım için birden fazla gözlem formu kullanıldığında, değerlendirilen kodlar için belirlenen "gözlem durumu" gözlemlerin ağırlıklı ortalaması alınarak belirlenmiştir. Gözlem formunda bulunan kategoriler her kazanımın BDİÖ̈ ile öğretiminin ardından yapılan öğrenci ve öğretmen yarı yapılandırılmış mülakatlardan elde edilen verilerle desteklenmiştir. Bu sayede derslerde var olan durum öğretmen ve öğrenci ifadeleriyle betimlenmeye çalışılmıştır. Verilerin sunulmasında öğretmen ve öğrencilerin isimleri araştırmaya, daha önceden kendilerine de belirtildiği üzere yansıtılmamıştır. Verilerin sunumunda, her kazanımın ardından mülakat yapılan öğrenciler $\mathrm{C} 1, \mathrm{C} 2, \ldots, \mathrm{C} 12$ ile kodlanmıştır. Odak grup mülakatı yapılan öğrenciler $\mathrm{C} 13$ ve $\mathrm{C} 14$ 
ile kodlanırken; ünitenin sonunda yarı yapılandırılmış mülakat yapılan öğrenciler ise C15,...C19 ile kodlanmıştır.

\section{Bulgular}

Bu bölümde, "öğrenme ortamı", "öğretmen davranışları", "takım davranışları" ve "BDİDÖ ortamında konik öğretimine ilişkin öğretmen ve öğrenci görüşleri" alt başlıkları altında bulgular sunulmuştur.

\section{Öğrenme Ortamı}

Kazanımların öğretiminde öğrenme ortamında gözlemlenen durumlar analiz edilerek Tablo $3^{\prime}$ te verilmiştir.

Tablo 3. Öğrenme Ortamı

\begin{tabular}{|c|c|c|c|c|c|}
\hline \multirow[b]{2}{*}{ Kategori } & \multirow[b]{2}{*}{ Kod } & \multicolumn{4}{|c|}{ Kazanımlar } \\
\hline & & 1. & 2. & 3. & 4. \\
\hline \multirow{3}{*}{ 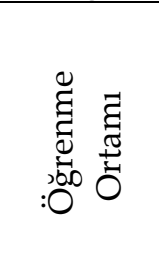 } & $\begin{array}{l}\text { BDIDÖ ortamının oluşturulmasında } \\
\text { bilgisayarlar etkin olarak kullanılmıştır. }\end{array}$ & 2 & 2 & 2 & 2 \\
\hline & $\begin{array}{l}\text { BDIDÖ ortamının oluşturulmasında } \\
\text { etkileşimli tahta etkin olarak kullanılmıştır. }\end{array}$ & 2 & 2 & 2 & 2 \\
\hline & $\begin{array}{l}\text { BDİDÖ ortamının oluşturulmasında işbirlikli } \\
\text { takımlar etkin çalışmışlardır. }\end{array}$ & 2 & 2 & 2 & 2 \\
\hline
\end{tabular}

Tablo 3 incelendiğinde işbirlikli takımların, davranışları BDİDÖ ortamına uygun olarak gerçekleştirildiği görülmektedir. Öğrencilerden C5, BDİDÖ ortamını;

"Oradaki noktaları bilgisayar üzerinde kendimiz hareket ettirerek, kavramlar görerek, tasdik ederek ve birlik içinde anlatarak çalıştı̆̆ımız için daha iyi öğrenmemizi sağladı."

sözleriyle betimlemiştir. Öğrencilerden C4, BDİDÖ ortamında bilgisayarların kullanımı ve işbirlikli çalışmalarla ilgili olarak;

"Şimdi 3 lü gruplar halinde çalışıyoruz. Bu daha fazla beynimizin yorum yapmasına neden oluyor. Denklemleri yazıp geçseydik ben bu konuları haftaya hatırlayamayacaktım arkadaşlarla tartışma üzerine bu bilgiler kuruldu. Herhalde en iyi öğrendiğim konulardan biri olacak elips. Uygulama yapıyoruz, mesela tek bir olay değil de değerler veriyoruz, sürekli değerleri değiştiriyoruz. Programda canlandırma özellikleri var, bu bazı şeyleri daha çabuk görebilmemize sebep oluyor."

şeklinde düşüncelerini belirtirken; ders öğretmeninin birinci kazanımın öğretiminden sonra yaptığ1 değerlendirme,

“Öncelikle öğrencilerden sekmedeki uzantıyı să̆a sola götürüp getirmelerini, oradaki bazı değişkenlerle oynamalarmı istedik. Çünkü ilk defa çalıştırdılar bu programı. Nasıl şey, neyle uğraşacaklar onu bilmeleri gerekiyordu. Baktılar işte oradaki sürgüleri oynattıkça şekillerde oynamalar oldu.Gençler bilgisayarı bizden daha iyi kavrıyorlar. Hemen orada birkaç oynama yaparak; bu şekilde yapinca burada oynamalar oluyor..."

sözleriyle olmuştur. Dördüncü kazanımın öğretiminden sonra ise, öğrenme ortamını şu şekilde değerlendirmiştir;

"Dinamik işbirlikli ortamda ilk ders işlediğimizde konumuz koniklerin sınıflandırılması sonra elipsti. Hiperbole göre daha kolaydı bu konular yani daha doğrusu hiperbol daha karmaşık. Asimptotu var içerisinde, hiperbolün kolları arasında oluşan bir dikdörtgensel bölge vs var. Yani biraz daha karmaşık yapısı vardı. Ama şimdi GeoGebra' yı ve öğrenme ortamını tanıdıkça üstesinden gelmeleri daha kolay oldu. Derse başlarken şimdi ne yapacaklarını biliyorlar. 'ne yapacağız? Bir sonuca ulaşmak için bir takım değişkenler üzerinde oynayacağız.' böyle bir başlangıçları var."

\section{Öğretmen Davranışları}

Kazanımların gerçekleştirildiği BDİDÖ ortamında gözlemlenen öğretmen davranışları "öğretmenin rolü" ve "bireysel değerlendirilebilirlik" kategorileri altında kodlar tanımlanarak gözlemlenmiştir. Buna göre gözlemlenen durumlar analiz edilerek Tablo 4 ' te sunulmuştur. 
Tablo 4. Öğretmen Davranışları

\begin{tabular}{|c|c|c|c|c|c|}
\hline \multirow[b]{2}{*}{ Kategori } & \multirow[b]{2}{*}{ Kod } & \multicolumn{3}{|c|}{ Kazanımlar } & \multirow[b]{2}{*}{4.} \\
\hline & & 1. & 2. & 3. & \\
\hline \multirow{9}{*}{ 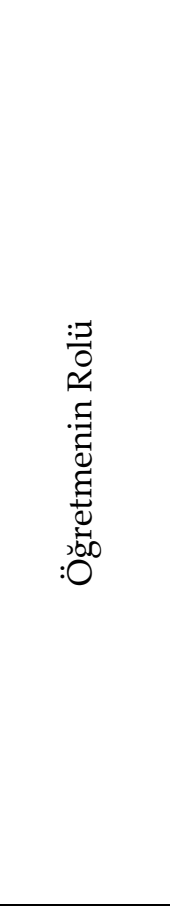 } & $\begin{array}{l}\text { Öğrencilerin seviye ve ilgilerine uygun } \\
\text { aktif katılımı sağlayıc öğrenme ortamı } \\
\text { oluşturuyor. }\end{array}$ & 2 & 2 & 2 & 2 \\
\hline & $\begin{array}{l}\text { Öğrencilere bilgiyi doğrudan vermek } \\
\text { yerine ipuçları veriyor. }\end{array}$ & 2 & 2 & 2 & 2 \\
\hline & Öğrenmeyi destekleyici dönütler veriyor. & 2 & 2 & 2 & 2 \\
\hline & $\begin{array}{l}\text { Öğrencilerin başkalarıyla paylaşımda } \\
\text { bulunmalarını sağllyor. }\end{array}$ & 2 & 2 & 2 & 2 \\
\hline & $\begin{array}{l}\text { Öğrencilerin etkileşimli tahta ve dinamik } \\
\text { materyallerden aktif olarak } \\
\text { yararlanmalarını sağlıyor. }\end{array}$ & 2 & 2 & 2 & 2 \\
\hline & $\begin{array}{l}\text { Öğretmen çalışmaları kolaylaştırıcı ve } \\
\text { hızlandırıcı rol üstleniyor. }\end{array}$ & 2 & 2 & 2 & 2 \\
\hline & $\begin{array}{l}\text { Kazanımı içeren uygun hazır bulunuşluk } \\
\text { düzeyini sorguluyor. }\end{array}$ & 2 & 2 & 2 & 2 \\
\hline & $\begin{array}{l}\text { Konuyla ilişkili temel kavram ve terimleri } \\
\text { hatırlatıyor. }\end{array}$ & 2 & 2 & 2 & 2 \\
\hline & $\begin{array}{l}\text { Etkileşimli tahta üzerinde dinamik } \\
\text { materyalleri etkin kullanıyor }\end{array}$ & 2 & 2 & 2 & 2 \\
\hline \multirow{2}{*}{ 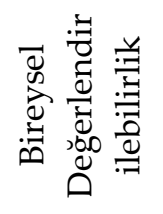 } & $\begin{array}{l}\text { Dinamik ortamda her öğrencinin derse } \\
\text { katılımı sağlanıyor. }\end{array}$ & 2 & 2 & 2 & 2 \\
\hline & $\begin{array}{l}\text { Her öğrencinin genellemeleri başarma } \\
\text { düzeyi takip ediliyor. }\end{array}$ & 2 & 2 & 2 & 2 \\
\hline
\end{tabular}

Tablo 4' te görüldüğü üzere gözlemlenen öğretmen davranışlarının ilk kazanımdan itibaren BDİDÖ ortamına uygun olarak gerçekleştirildiği belirlenmiştir. Ders öğretmenin aktif katılımı sağladığı ve ipuçları vererek öğrencilerin sorularına dönütler verdiği görülmüş̧ür. Öğretmen, öğrenme ortamında yaşanan durumu ve öğrencilerle aralarında geçen konuşmaları;

"Sonrasinda sinıfa genel olarak soruyu sorduğumuzda; 'bu oran ne olduğunda elips, ne olduğunda parabol, ne olduğunda da hiperbol?' kendileri zaten sonucu belirlediler. Belki bazen işte '0,94 e kadar' dediler. 'Peki 0,99 olsaydı ne olacaktı? Tahmininiz nedir, sezgileriniz nedir en azından?' dediğimizde; 'hocam bu sadece 1 olduğunda parabol olur, 1'den küçük olduğunda elips, büyük olduğunda hiperbol olur' onu kendileri fark ettiler. Oradaki dış merkezliğin ne anlama geldiğini, o P noktasının hangi mantıkla hareket ettiğini kendileri çıkardılar. Zaten aralarda dolaşırken öğrencilerde bize soru sordular. Burada en güzel yönü şu oldu; kendileri bir şeyler ortaya çıkardılar, kafalarında oluşan kendilerine ait soruları sorup o boşlukları doldurdular."

şeklinde ifade etmiştir. Öğretmenin, ders esnasında ipucu ve geri dönütlerle takımlara rehberlik ettiği, genellemeleri başarma düzeylerini takip ettiği gözlenmiştir. Ayrıca yapılan mülakatta da öğrenme ortamıyla ilgili gözlemlerini;

“Yine bazı öğrenciler birbiriyle tartışıyorlar, hafif bir gürültü ortamı oluyor gibi ama çok rahatsız edici değil. Orada birbirleriyle tartıştıklarını, sorular sorduklarını fark ediyoruz. Hatta bazen beni duymadıkları oluyor. Bakıyorum birbirlerine burası böyle olacak diyor, 'bu niye böyle oluyor?' işte şundan dolayı diyenler oluyordu, yani kulağımıza geliyordu. Bu da bize soramadıkların rahatlıkla arkadaşlarına sorabilmelerinin avantajı olarak güzel bir öğrenim oluyordu."

sözleriyle belirtmiştir. Öğretmenin takımların genellemeleri uygulayabilmeleri üzerine;

“Öğrencilerin kendilerinin sonucu elde ettikleri bir örnek sorduğumuzda önce koordinat düzlemi çizip orada verilen noktaları yerleştirdiler. Burada az önceki sonuçları elde ederken ne yaptılarsa aynılarım tekrar yaparak olayı çözdüler. Bazıları grafiği çizmeden çözdü ama onlarda da fark ettik ki sorduğumda, zihninde çizmiş." 
şeklinde gözlem yaptığı belirlenirken, C6'nın ise, derste gerçekleşen durumu;

"Zaten artık programa gerek kalmıyor yani. Kafada canlandırabiliyorduk onu. Kafadaki canlandırmaya göre yine aynı şekilde değerleri yerlerine yerleştirerek yaptık."

sözleriyle değerlendirdiği görülmüştür. Ders öğretmeni, öğretmenlerin bu konuyu öğretirken hiperbol ile asimptotların birbirine göre durumunun açıklanabileceğini;

“ Tabii daha önce hiç asimptot kavramı görmediler ve asimptot esasen önümüzdeki senenin konusu. Orada bir ek açıklama yaptık. Yani bu doğrunun anlamı nedir diye. Çünkü asimptotu bilmiyorlar, tanımı da bilmiyorlar. Yorum yapmaları pek mümkün olmayabilir. Bir de orada şekli biraz küçültmelerini istedik yani ilerde gittikçe teğetleşiyor gibi. Asimptot hiperbolün iç bölgesine geçmiyor bunu gördüler de. Orada biz bir ek açıklama yaptık ve asimptot kavramının ne olduğuna dair bazı günlük yaşamdan da bir iki örnek verdik asimptot kavramını anlamalarına dönük. Yani bazen bazı grafiklerin bazı doğrulara sürekli olabildiğince yaklaşabileceklerini ama asla değmeyeceği durumunun olabileceğine dair bir iki de örnek verdik."

sözleriyle ifade etmiştir. Öğrencilerden C9, yapılan mülakatta bu noktaya değinerek;

“Geometri görsel bir ders olduğu için bilgisayarda öğrenilmesi daha iyi. Ama burada sabit noktaları, hareketli noktaları incelerken o değerleri birebir gözlemleyebiliyoruz. Tahtada tam çizilemiyor, teğetleri falan tam göremiyoruz. Asimptotlar hiçbir zaman hiperbole değmez. Ama tahtada çizim yaparken herhangi bir cetvel falan kullanmadığımı için bazen birleşebiliyor. Bu nedenle de bilgisayarla öğrenme daha iyi olduğunu söyleyebiliriz."

şeklinde açıklama yapmıştır. ayrıca, öğrencilerin ilk kazanımda elde ettikleri parabolün dış merkezliği ile son kazanımda elde ettikleri genellemeyi ilişkilendirebildiklerini gözlemlediğini;

“PF (P noktasının odağa uzaklığı) uzunluğunun Pd (P noktasının d doğrusuna uzaklığı) uzunluğuna oranının 1 olduğunu ve parabol olduğu için bunun değişmeyeceğini zaten orada fark etmiş oldular. Evet, oradaki dış merkezlik olan e' ninde 1 olduğunu görerek de bazıları zaten hakikaten parabol olduğunu bunun yardımıyla anladıklarını fark ettiler. Mesela bazı öğrenciler sadece şekil parabole benziyor demek ki bu parabol diyor. Ama orada o eşitliği görüp; bu hakikaten parabol olduğunu yapan öğrenciler de oldu. Konik oluşumu tanımından da bağdaştırarak buldular."

sözleriyle ifade ederken; öğrencilerden C12, bu durumu şöyle belirtmiştir;

“Uzaklikları eşit olduğunu belli oran çıktı̆̆ını deneyerek kendimiz bulduk. Koordinat sisteminde olduğu yer gözümün önüne geliyor."

\section{Takım Davranışları}

Verilen kazanımın BDİDÖ ile öğretiminde gözlemlenen takım davranışları "takım ödülü/ortak ödül", "olumlu bağımlılık", "yüz yüze (destekleyici) etkileşim", "sosyal beceriler", "değerlendirme" ve "eşit başarı fırsatı" kategorileri altında kodlar tanımlanarak gözlenen durumlar analiz edilmiş ve Tablo $5^{\prime}$ te verilmiştir.

Tablo $5^{\prime}$ te verilen, takım davranışlarında gözlemlenen sonuçlar incelendiğinde birinci kazanımın öğretiminde takımların materyalleri kullanarak genellemelere ulaşmayı BDİDÖ ortamına uygun olarak gerçekleştirmeye yakın oldukları, genellemelerin cebirsel ifadelerini tanımlamayı ise yüzeysel olarak gerçekleştirdikleri belirlenmiştir. Takımların kodlarda verilen bazı davranışları yüzeysel olarak gerçekleştirdikleri, diğer davranışları ise BDİDÖ ortamına uygun olarak gerçekleştirmeye yakın oldukları görülmektedir. Öğrencilerden C1, koniklerin sınıflandırılmasında materyalleri kullanarak ve takım olarak çalıştıklarında;

"e nin sabit bir değer olduğunu gördüm. O değerin 1'den küçük olduğunda elips, 1 olduğunda parabol, 1'den büyük olduğunda hiperbol olduğunu ve orada sürgüyü değiştirerek şekillerin değiştiğini gördük. Yani hangi aralıkta hangi ş̧ekillerin oluştuğunu gördük. Ayrıca o oranın (e) değişmediğini şekiller üzerinde sürekli değiştirerek gördük." şeklinde elde ettikleri genellemeyi açıklamıştır. 
Tablo 5. Öğrenci Takım Davranışları

\begin{tabular}{|c|c|c|c|c|c|}
\hline \multirow[b]{2}{*}{ Kategori } & \multirow[b]{2}{*}{ Kod } & \multicolumn{3}{|c|}{ Kazanımlar } & \multirow[b]{2}{*}{4.} \\
\hline & & 1. & 2. & 3. & \\
\hline \multirow{3}{*}{ 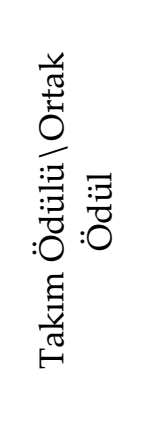 } & $\begin{array}{l}\text { Takım üyeleri takım başarısını artırmak } \\
\text { için çalışmaktadırlar (işbirlikli iş yapısı). }\end{array}$ & 1.6 & 1.7 & 1.7 & 1.8 \\
\hline & $\begin{array}{l}\text { Takım üyeleri dinamik materyalleri } \\
\text { kullanarak çalışma yapraklarındaki } \\
\text { genellemelere ulaşabiliyor. (işbirlikli ödül } \\
\text { yapısı) }\end{array}$ & 1.7 & 2 & 1.8 & 1.8 \\
\hline & $\begin{array}{l}\text { Takım üyeleri materyalleri kullanarak } \\
\text { genellemelerin cebirsel ifadelerini } \\
\text { tanımlayabiliyor. }\end{array}$ & 1.3 & 2 & 1.8 & 1.8 \\
\hline \multirow{4}{*}{ 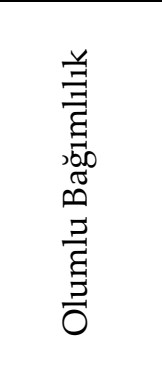 } & $\begin{array}{l}\text { Takım üyeleri sorumluluklarını yerine } \\
\text { getiriyor. }\end{array}$ & 1.2 & 1.7 & 1.7 & 1.8 \\
\hline & $\begin{array}{l}\text { Takım üyeleri birbirlerinin } \\
\text { öğrenmelerinden sorumlu davranıyor. }\end{array}$ & 1.6 & 1.7 & 1.7 & 1.8 \\
\hline & $\begin{array}{l}\text { Takım üyeleri dinamik materyalleri ve } \\
\text { çalışma yapraklarını etkin kullanıyor. }\end{array}$ & 1.8 & 2 & 1.9 & 1.9 \\
\hline & $\begin{array}{l}\text { Takım üyeleri işbirliği ve dayanışma } \\
\text { içerisinde davranıyor. }\end{array}$ & 1.4 & 1.7 & 1.7 & 1.8 \\
\hline \multirow{6}{*}{ 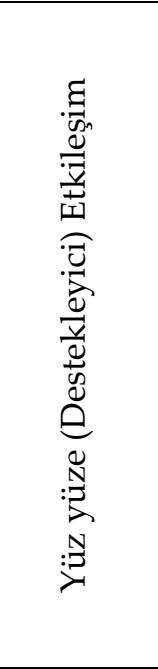 } & $\begin{array}{l}\text { Takım üyeleri yüz yüze etkileşimde } \\
\text { bulunuyor (yardım etme). }\end{array}$ & 1.8 & 2 & 1.7 & 1.8 \\
\hline & $\begin{array}{l}\text { Takım üyeleri birbirlerini } \\
\text { cesaretlendiriyor (güvenme). }\end{array}$ & 1.6 & 1.9 & 1.7 & 1.8 \\
\hline & $\begin{array}{l}\text { Konunun anlaşılmayan kısımları } \\
\text { belirleniyor (dönüt verme). }\end{array}$ & 1.2 & 2 & 1.7 & 1.8 \\
\hline & $\begin{array}{l}\text { Takım üyeleri dinamik materyallerin } \\
\text { kullanımını birbirlerine anlatıyor. }\end{array}$ & 1.8 & 2 & 1.9 & 1.9 \\
\hline & $\begin{array}{l}\text { Öğrenciler birbirlerinin yanlışlarını } \\
\text { düzeltiyor. }\end{array}$ & 1.2 & 1.8 & 1.7 & 1.8 \\
\hline & $\begin{array}{l}\text { Takım üyeleri dinamik materyalleri } \\
\text { birlikte tartışıp inceleyerek genellemelerde } \\
\text { karşılaştıkları problemleri çözüme } \\
\text { kavuşturuyor. }\end{array}$ & 1.1 & 1.8 & 1.7 & 1.8 \\
\hline \multirow{3}{*}{ 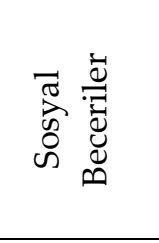 } & $\begin{array}{l}\text { Takım üyeleri etkinlikler başlamadan önce } \\
\text { bir süre bir arada bulunuyor. }\end{array}$ & 1.7 & 1.8 & 1.9 & 1.9 \\
\hline & $\begin{array}{l}\text { Takım üyeleri birbirleriyle iyi ilişkiler } \\
\text { kurabiliyor. }\end{array}$ & 2 & 2 & 2 & 2 \\
\hline & Takım üyeleri birbirlerini dinliyor. & 1.9 & 2 & 2 & 2 \\
\hline \multirow{2}{*}{ 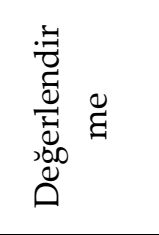 } & $\begin{array}{l}\text { Takım üyeleri etkinliğin sonunda } \\
\text { vardıkları genellemeleri değerlendiriyor. }\end{array}$ & 1.1 & 1.9 & 1.7 & 1.8 \\
\hline & $\begin{array}{l}\text { Takım üyeleri etkinliğin sonunda elde } \\
\text { edilen genellemeyi diğer takımlarla } \\
\text { birlikte sorguluyor. }\end{array}$ & 1 & 1.6 & 1.7 & 1.8 \\
\hline \multirow{2}{*}{ 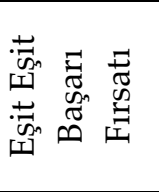 } & $\begin{array}{l}\text { Takım üyeleri kendilerini geliştirerek } \\
\text { genellemelere katkıda bulunuyor. }\end{array}$ & 1.4 & 1.8 & 1.7 & 1.8 \\
\hline & $\begin{array}{l}\text { Genellemelere varılırken her öğrencinin } \\
\text { katkısı değerlendirmeye alınıyor. }\end{array}$ & 1.6 & 1.8 & 1.6 & 1.8 \\
\hline
\end{tabular}

Tablo $5^{\prime}$ te verilen öğrenme ortamında gözlemlenen sonuçlar incelendiğinde ikinci kazanımın öğretiminde takımların materyalleri kullanarak genellemelere ulaşmayı ve genellemelerin cebirsel ifadelerini tanımlamayı BDİDÖ ortamına uygun olarak gerçekleştirdikleri belirlenmiştir. Aynı şekilde takımların kodlarda verilen diğer davranışların tamamını BDİDÖ ortamına uygun olarak gerçekleştirdikleri ya da 
gerçekleştirmeye çok yakın oldukları görülmektedir. Öğrencilerden C5, genellemelere ulaşırken takım arkadaşlarıyla tartışarak birlik içinde olduklarını;

"Illk önce noktayı oynattık; takım arkadaşlarımla yorum yaptık ve ona göre tartışarak ulaştık. Aynı doğrultu üzerindeki sabit iki noktanın $F_{1}$ ve $F_{2}$ noktasının belli bir P noktasına uzaklıkları toplamı sabit olan noktalar kümesi olduğunu ve oradaki uzunlukları tespit ettik. "Kavramları hareket ettirdik. Bu biraz daha gerçekçi oldu. Kendimiz hissedip, kendimiz görerek konuyu işlemiş olduk."

sözleriyle ifade ederken; C6, takımdaki her öğrencinin öğrenebildiğini şu sözlerle belirtmiştir;

“Önce verileri elde ediyorduk ondan sonra işte tartışarak öğrenmemizi sağllyor. Sadece bir kişi değil diğer gruptaki arkadaşlarda aynı seviyede öğrenebiliyor. Ben sadece anlatılmasıyla öğrenemiyordum. Fakat bu öğrenme ortamı sayesinde daha da aklımda kaldı."

Ders öğretmeni, elipste yer alan genellemelerin cebirsel ifadelerinin yazılabildiğini;

"PF1+PF2 nin $2 a$ ya eşit olduğunu hemen hemen herkes elde etti. Ben orada yani sıkıntı olur diye düşünüyordum. Yine, $b^{2}+c^{2}=a^{2}$ Pisagor bağıntısını gördüler. Pisagor' u görmüş olmaları zaten elipste birçok şeyi halledebileceklerini gösteriyor."

ifadeleriyle açıklamıştır.

Tablo $5^{\prime}$ te görüldüğg̈ üzere üçüncü kazanımın öğretiminde takımların materyalleri kullanarak genellemelere ulaşmayı ve genellemelerin cebirsel ifadelerini tanımlamayı BDİDÖ ortamına uygun olarak gerçekleştirmeye çok yakın oldukları belirlenmiştir. Aynı şekilde takımların kodlarda verilen diğer davranışların tamamını BDİDÖ ortamına uygun olarak gerçekleştirdikleri ya da gerçekleştirmeye çok yakın oldukları görülmektedir. Öğrencilerden C9, materyalleri kullanarak genellemelere ulaşabildiklerini;

"Genellemelere birkaç tane deney yaparak deney dediğim değer vererek, ondan sonra kendi bilgilerimizle yardımlaşarak kendi takımımı arasında bilgisayardan görerek ve inceleyerek genellemelere vardik. Belli bir noktayı değiştirerek, değerleri sürükleyerek hiperbolü çizdik öncelikle, ondan sonra noktalar arasındaki uzaklıkları görerek, arttıkça artar mı değerler, azaldıkça azalır mı öğrendik."

ifadeleriyle belirtmiştir.

Takımların çalışma yaprakları incelendiğinde "Asimptot doğruları hiperbol grafiğine her zaman yaklaşır ama hiç kesişmez." şeklinde açıklama yaptıkları ve ders esnasında da hiperbol kolları üzerindeki noktayı canlandırma sekmesini kullanarak hareket ettirdikleri ve doğruların hiperbole göre durumunu kendi aralarında tartıştıkları gözlenmiştir. Bu durum üzerine ders öğretmeni ile etkileşime girdikleri belirlenmiştir. Nitekim ders öğretmeni, yapılan mülakatta durumu;

"Noktaların farklı değerler almasını hocam sonsuza mı gidiyor şeklinde soruya neden oldu. Sonsuza gittiğinde yaklaşacağını söyleyince tabii şekil üzerinde madem sonsuza kadar gidiyor mesela hiperbolün bir noktasında sonsuza gidince bir yerden sonra hop diğer kola hiperbolün diğer koluna geçiyor. Sonsuza kadar gidecek madem niye sonsuza kadar gitmedi? gibi bir soru işareti oldu. Orada da şöyle bir açılama yaptık; esasen teorik olarak orası sonsuza kadar gidiyor ama bilgisayar da nihayetinde ne diyelim kul yapısı (gülüyor). Belli bir sayı aralığı üzerinde hareket ediyor. 0.01 üzerinden hareket etse bile bir yerden sonra oradaki yaklaşımı atlayacaktır. Bundan dolayı diğer kısma geçis yapacaktır. Teorik ve pratik arasındaki farkı da burada biraz ifade etmiş olduk öğrencilere."

sözleriyle açıklamıştır.

Tablo $5^{\prime}$ te verilen dördüncü kazanımın öğretiminde takımların materyalleri kullanarak genellemelere ulaşmayı ve genellemelerin cebirsel ifadelerini tanımlamayı BDIDÖ ortamına uygun olarak gerçekleştirmeye çok yakın oldukları belirlenmiştir. Aynı şekilde takımların kodlarda verilen diğer davranışların tamamını BDIDÖ ortamına uygun olarak gerçekleştirdikleri ya da gerçekleştirmeye çok yakın oldukları görülmektedir. Öğrencilerden C12, özgüvenlerinin olduğunu;

"Daha önce konikleri hiç duymamıştım bilmiyordum ne olduğunu. İşbirlikli ortamda da bir özgüven eksikliği olduğunda korkmuyoruz çünkü diyoruz ki biz yapamazsak arkadaşlarımız bize öğretir. Çünkü hocamız başında söylemişti; arkadaşlarmızın da öğrenmelerinden sorumlusunuz diye. Bu bence güven veriyor."

ifadeleriyle açıklamıştır. 


\section{BDİDÖ Ortamında Konik Öğretimine İlişkin Öğretmen ve Öğrenci Görüşleri}

$\mathrm{Bu}$ kısımda veriler, Konikler ünitesinin BDID öğretimi tamamlandıktan sonra öğretmen ve öğrencilerle gerçekleştirilen yarı yapılandırılmış mülakatlar ve başarılı takımla gerçekleştirilen yarı yapılandırılmış odak grup mülakatından elde edilmiştir.

\section{BDIDÖ Ortamında Konikleri Öğrenme Hakkındaki Görüşler}

Öğrencilerin ve ders öğretmeninin yapılan mülakatlarda 'Konikler ünitesini BDİDÖ ortamında öğrenme ile ilgili neler düşünüyorsunuz?' ve 'Öğrencilerin BDİDÖ yoluyla konikler ünitesini öğrenmeleri hakkında neler düşünüyorsunuz?' sorularına verdikleri cevaplar analiz edilerek elde edilen bulgular kodlar halinde Tablo 6' da sunulmuştur.

Tablo 6. BDIDÖ Ortamında Konikleri Öğrenme Hakkındaki Görüşler

\begin{tabular}{|c|c|c|c|}
\hline Kategori & Kod & fö̆renci & Öğretmen \\
\hline \multirow{14}{*}{ 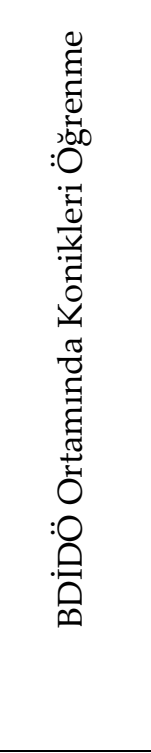 } & Kalıcı öğrenmeyi sağlıyor & 5 & $\checkmark$ \\
\hline & Tanımları yapabilmeyi sağlıyor & 5 & \\
\hline & Derse olan ilgiyi artırıyor & 3 & $\checkmark$ \\
\hline & Kolay öğrenmeyi sağlıyor & 3 & $\checkmark$ \\
\hline & Ezberlemeden öğrenmeyi sağlıyor & 3 & \\
\hline & Dersi daha zevkli yapıyor & 3 & \\
\hline & $\begin{array}{l}\text { Analitik Geometriyi soyut bir ders olmaktan } \\
\text { çıarıyor }\end{array}$ & 2 & $\checkmark$ \\
\hline & Daha çok örneği uygulayarak çözmeyi sağlıyor & 2 & \\
\hline & Hızlı öğrenmeyi sağlıyor & 2 & \\
\hline & Analitik geometriyi sevmeyi sağlıyor & 1 & \\
\hline & Deneyerek öğrenmeyi sağlıyor & 1 & \\
\hline & Dikkati topluyor & 1 & \\
\hline & Konuyu pekiştirmeyi sağlıyor & 1 & \\
\hline & $\begin{array}{l}\text { Öğrencinin kendisinin çıkarımda bulunmasını } \\
\text { sağlıyor }\end{array}$ & 1 & $\checkmark$ \\
\hline
\end{tabular}

Tablo 6’ ya bakıldığında öğrencilerin ve ders öğretmeninin BDİDÖ ortamında konikler ünitesini öğrenmenin daha çok, kalıcı ve kolay öğrenmeyi sağladığını ve derse olan ilgiyi artırdığını belirttikleri görülmektedir. Öğrencilerden C18, BDİDÖ ortamının kalıcı öğrenme sağladığını;

"Biz burada kendimiz uyguluyoruz, kendimiz keşfediyoruz tanımları. Ben 3 hafta önce öğrendiğim şeyi şimdi halen daha beynimde canlandırabiliyorsam bu uygulama sayesinde. Yoksa ben kitaptan çalışsaydım inanın şu grafikler benim aklımda olmazdı. Ama biz kendimiz yaparak öğrendiğimiz için bir şekilde hatırlıyorsunuz, grafik beyninizde canlanıyor o yüzden kahıcılı̆̆ ı çok iyi."

ifadesiyle belirtirken; C16, derse ilgisinin arttığını ve analitik geometriyi sevmeye başladığını;

"Ben kısacası söyleyeyim; analitik geometriyi pek sevmezdim. Ama yani bu programdan sonra da analitiklere biraz daha olsun sevmeye, biraz ilgim oldu. Çünkü sayısal bölümündeyiz; şekilleri seviyoruz. Şekiller üzerinde çalışııoruz sürekli."

sözleriyle ifade etmiştir. Ders öğretmeni ise, öğrencinin kendisinin çıkarımda bulunarak daha kalıcı öğrenmeler gerçekleştirdiğini;

“Öğrenciler genel itibariyle birçok yerde tahminimin üzerinde uygun, doğru sonuçlar çıkardılar. Bu yönüyle de değerlendirmede bulunursak ee zannediyorum hem kalıcılık açısından hem öğrencilerin sonuca kendilerinin ulaşması yönüyle olumlu olmuştur diye düşünüyorum."

ifadeleriyle belirtmiştir.

\section{Dinamik Materyal, Çalışma Yapraklan ve İşbirlikli Çalışma Hakkındaki Görüşler}

Öğrencilerin ve ders öğretmeninin yapılan mülakatlarda 'Uygulamalar sırasında gözlemleriniz ve değerlendirmeleriniz nelerdir?' sorusuna verdikleri cevaplar analiz edilerek elde edilen bulgular kodlar halinde Tablo 7 ve Tablo 8' de sunulmuştur. 
Tablo 7. Dinamik Materyal ve Çalışma Yaprakları Hakkındaki Görüşler

\begin{tabular}{|c|c|c|c|}
\hline Kategori & Kod & föğrenci & Öğretmen \\
\hline \multirow{8}{*}{ 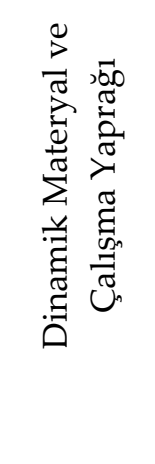 } & $\begin{array}{l}\text { Dinamikliği kullanarak değişkenlere farklı değerleri } \\
\text { verebilmeyi sağlıyor }\end{array}$ & 6 & $\checkmark$ \\
\hline & Konuyu görselleştiriyor & 6 & $\checkmark$ \\
\hline & Değerler arasındaki farkları ayırt etmeyi sağlıyor & 6 & $\checkmark$ \\
\hline & $\begin{array}{l}\text { Öğrencinin kendisinin uygulama yaparak } \\
\text { öğrenmesini sağlıyor }\end{array}$ & 5 & $\checkmark$ \\
\hline & Konuyu görselleştiriyor & - & $\checkmark$ \\
\hline & Konuyu somutlaştırıyor & 4 & \\
\hline & Şekillerin kolaylıkla gözlenmesini sağlıyor & - & $\checkmark$ \\
\hline & Üzerinde çalışma-uygulama yapılabiliyor & - & $\checkmark$ \\
\hline
\end{tabular}

Tablo 7 incelendiğinde öğrencilerin ve ders öğretmenlerinin daha çok, değişkenlere farklı değerler verebilme, konuyu görselleştirme ve değerler arasındaki farkları ayırt etmeyi sağlayabilmesi açısından materyal ve çalışma yapraklarını değerlendirdikleri görülmektedir. Öğrencilerden C16, materyallerin konuyu görselleştirdiğini ve üzerinde çalışma-uygulama yapılabildiğini;

"Üzerinde çalışma olană̆ı olarak uğraştı̆̆ımız için, mesela noktaları oynattı̆̆ımız zaman görsel olması. Bazı yerler değişiyor, büyüyor, küçülüyor."

ifadeleriyle açıklarken dinamikliğin değerler arasındaki farkları ayırt etmeyi sağladığını şu sözlerle belirtmiştir;

"Oynatmak mesela diğer bir şekille onun arasındaki farkı ayırt etmemize neden oluyor. Mesela az önce yaptığımız zaman oran 1 oluyorsa şimdi 2 oluyor. Bunu görüyoruz, farkı ayırt ediyoruz ikisi arasındaki farkı. Bunu gördüğ̈̈müz zaman ve ikisi arasındaki farkı öğrendiğimiz zaman zaten ikisini de öğrenmiş oluyoruz otomatik."

C18 ise, öğrencinin kendisinin uygulama yaparak öğrenmesini şu şekilde ifade etmiştir;

"Şimdi hocamız; 'Çocuklar $x^{2} / a^{2}+y^{2} / b^{2}$ işte a bura, b bura, işte 1 e eşit. Ben bunu istemiyorum. Burada a yı ayrı buluyorsun; ben buluyorum, b yi ben buluyorum. Bunu da yerleştirecek olan benim. O zaman çok güzel bir şey yani. Ben yaptım. Eureka diyesimiz geliyor (gülüyor)."

Tablo 8. Lise Öğrencilerinin İşbirlikli Çalışma Hakkındaki Görüşleri

\begin{tabular}{|c|c|c|c|}
\hline Kategori & Kod & föğrenci & Öğretmen \\
\hline \multirow{14}{*}{ 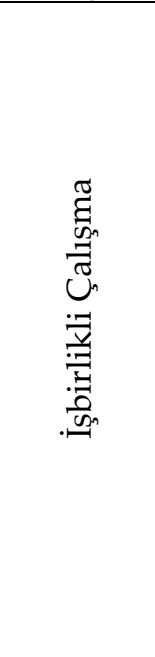 } & Birlikte öğrenmeyi sağlıyor & 6 & $\checkmark$ \\
\hline & Özgüven sağllyor & 5 & \\
\hline & Arkadaşlar arasındaki ilişkileri güçlendiriyor & 4 & \\
\hline & Fikirleri paylaşmayı sağlıyor & 4 & \\
\hline & Takımla çalışabilmeyi öğretiyor & 4 & \\
\hline & Takım arkadaşlarının birbirine güvenmesini sağlıyor & 3 & \\
\hline & Takımdaki her öğrencinin öğrenmesini sağlıyor & 3 & $\checkmark$ \\
\hline & Tartışabilmeyi sağlıyor & 3 & \\
\hline & Topluma uyum sağlayabilmeyi öğretiyor & 3 & \\
\hline & Birlik duygusu oluşturuyor & 2 & \\
\hline & Sorumluluk hissettiriyor & 2 & \\
\hline & Birden fazla beceriyi aynı anda kullanmayı sağlıyor. & 1 & \\
\hline & Hatayı düzeltebilme firsatı sağlıyor & 1 & \\
\hline & Yardımlaşmayı sağlıyor & 1 & $\checkmark$ \\
\hline
\end{tabular}

Ders öğretmeni ise öğrencilerin materyal ve çalışma yaprakları üzerinde uygulama yapılabiliyor olmalarını, şekillerin kolaylıkla gözlenmesini sağladığını ve konuyu görselleştirdiğini; 
"Beyninin să̆ tarafin da işin içine sokmaları yani hayal etmeleri, şekilleri zihinde oluşturma, neyin neye yerleştireceklerini, oradaki soyut terimlerin sayısal terimlerin, işlemlerin, şekil üzerinde neye tekabül ettiğini görmeleri yönüyle çok iyi oldu bu yönü."

sözleriyle dile getirmiştir.

Tablo 8 ' e bakıldığında öğrencilerin ve ders öğretmeninin daha çok, işbirlikli çalışmanın birlikte öğrenmeyi sağladığını belirttikleri görülmektedir.

C15, işbirlikli çalışmanın arkadaşlar arasındaki ilişkileri güçlendirdiğini, takımla çalışabilmeyi ve topluma uyum sağlayabilmeyi öğrettiğini;

"Kişi arasındaki ilişkileri güçlendiriyor. Takımla çalışmayı öğretiyor ve bu da bir birliktelik sağhıyor toplum içerisinde."

ifadeleriyle dile getirmiştir. C17, fikirleri paylaştıklarını;

"Yeni bir şeyler ortaya yeni fikirler ortaya koyuyoruz o çok güzel oluyor. Benim bittiğim yerde arkadaşım başlıyor."

sözleriyle ifade ederken, ders öğretmeni, öğrencilerin işbirlikli çalışmalarının tartışabilmeyi, birlikte öğrenmeyi ve takımdaki her öğrencinin öğrenmesini sağladığını;

"Birinin anlamadığı yeri diğerine sordu. Bu nasıl olur gibi sorular sordular. Diğeri de; şu şurada değişti, bak burası böyle denk geldi bundan dolayı bu sonucu elde ettik gibi cevaplar verdiler. Zaten 3 kişi bir arada yaparken birinin bilmediğini diğeri fark edince diğeri yapmış oldu."

ifadeleriyle açıklamıştır.

\section{Öğrenmeyi Etkileyen Faktörler Hakkındaki Görüşler}

Öğrencilerin ve ders öğretmeninin yapılan mülakatlarda ‘BDIDÖ ortamı üniteyi öğrenmenizi nasıl etkiledi?' ve 'BDİDÖ ortamında öğrencilerin öğrenmelerini etkileyen faktörler neler oldu?' sorularına verdikleri cevaplar analiz edilerek elde edilen bulgular kodlar halinde Tablo 9' da sunulmuştur.

Tablo 9. Lise Öğrencilerinin Öğrenmeyi Etkileyen Faktörler Hakkındaki Görüşleri

\begin{tabular}{|c|c|c|c|}
\hline Kategori & Kod & föğrenci & Öğretmen \\
\hline \multirow{9}{*}{ 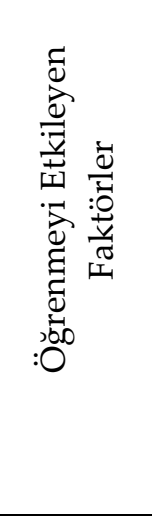 } & $\begin{array}{l}\text { Bireysel veya takım halinde materyalleri } \\
\text { uygulayabilmek }\end{array}$ & 6 & \\
\hline & Değişkenlerin faklı değerlerini görebilmek & 4 & $\checkmark$ \\
\hline & Genellemelere ortak bir kararla varabilmek & 4 & \\
\hline & Genellemelere tartışarak varabilmek & 4 & $\checkmark$ \\
\hline & $\begin{array}{l}\text { Varılan genellemelerin doğruluğunu } \\
\text { gözlemleyebilmek }\end{array}$ & 4 & $\checkmark$ \\
\hline & Parçadan bütünü oluşturmak & & \\
\hline & Ders öğretmeninin rehber olması & 2 & \\
\hline & İzleme testlerinin yapılması & - & $\checkmark$ \\
\hline & Öğrencilerin derste aktif rol oynaması & 1 & $\checkmark$ \\
\hline
\end{tabular}

Tablo 9 incelendiğinde öğrencilerin öğrenmeyi etkileyen 8 farklı faktör, ders öğretmeninin ise 5 farklı faktör belirlediği görülmektedir. Öğrenciler öğrenmeyi etkileyen faktörler olarak daha çok, bireysel veya takım halinde materyalleri uygulayabilmek olduğunu belirtirken, ders öğretmeni ise konikleri öğrenmeyi etkileyen faktörler olarak değişkenlerin farklı değerlerini görebilmeyi, öğrencilerin derste aktif rol oynamasını, izleme testlerinin yapılmasını, genellemelere tartışarak varabilmeyi ve doğruluğunu gözlemleyebilmeyi belirtmiştir. Öğrencilerden C16, genellemelere tartışarak vardıklarını;

"Yanlış yaptığımızda mesela ben yorumumu koydum; mesela dedim ki şu şöyle olunca şöyle oluyor. Diğeri ya destekledi ya da dedi ki bu aslında böyle olmayabilir. Ya da o da bir daha baktı, bir daha okuduk soruyu. Yani değerlendirdik, dedik bunu yazalım dedik; beraber bunu yazdik."

sözleriyle açklarken, C18, varılan genellemelerin doğruluğunu gözlemlediklerini; 
"Bu değeri verelim, şu değeri verelim; şu değer için şu çıkıyor. Bakıyoruz, farklı bir nokta seçiyoruz bu değgerde şu, şu şu. Bakıyoruz sağlıyor; ne kadar güzel."

sözleriyle ifade etmiştir. C13, öğrencilerin derste aktif rol oynadığını ve ders öğretmenlerinin takımlara rehber olduğunu;

"Dikkat ettiğimiz bir soru şuydu öğretmenimize ne sormuşsak tam manasıyla bize direkt cevabını vermedi. Bir ipucu vererek bizim görmemizi sağladı. Bu şekilde yine öğrenci merkezli bir öğretim stratejisi sağlanmış oldu."

şeklinde açıklamıştır. Ders öğretmeni ise, öğrencilerin genellemelere tartışarak vardıklarını;

"Zihinlerini çalıştırıyorlar bu sonuca gitmek için ne yapabiliriz? Direkt bu sonuca gidilmek için şu yapılıyormuş değil de bu sonuca gitmek için biz ne yapabiliriz? Nasıl bir yöntem uygulayabilirim gibi sorgulamaları da yaptırıyor öğrenciye. Zihinde bir yol oluşturuyor."

ifadeleriyle belirtirken; izleme testleri sayesinde öğrencilerin konuyu derste öğrenmek zorunda olduklarını hissettiklerini;

"İzleme testi, öğrenciler ders sonunda ve bir iki hafta sonrasında konu bitiminde ünite bitiminde sınav olacağını bildiği için yani "benim sınavım birinci sınavım iki ay sonra, iki ay sonra son akşam derse çalışayım, geçerim" olayı kalktı. Bu ders sonunda öğrenci bilir ki her dersin sonunda bana bir sinav yapılacak ve ben bunu anlamalıyım."

sözleriyle açıklamıştır. Öğretmen bu durumla ilgili olarak düşüncelerini şu ifadelerle açıklamıştır; “Öğrenciler şekil çizerek, onun üzerinde verileri yerleştirerek yavaş yavaş bilgileri çă̆ıra çağıra sonuca ulaştılar."

\section{Genellemelere Varma Hakkındaki Görüşler}

Öğrencilerin ve ders öğretmeninin yapılan mülakatlarda ‘BDİDÖ ortamında genellemelere varmanız hakkında neler düşünüyorsunuz?' ve 'Öğrencilerin BDIDÖ ortamında genellemelere varmaları hakkında neler düşünüyorsunuz?' sorularına verdikleri cevaplar analiz edilerek elde edilen bulgular kodlar halinde Tablo 10' da sunulmuştur.

Tablo 10. Lise Öğrencilerinin Genellemelere Varma Hakkındaki Görüşleri

\begin{tabular}{llcc}
\hline Kategori & Kod & fögrenci & Öğretmen \\
\hline Elips, hiperbol ve parabolü kavramsal olarak & 6 & $\checkmark$ \\
& anlayabilmeyi sağlıyor & 5 & $\checkmark$ \\
Dış merkezliği tanımayı sağlıyor & 5 & $\checkmark$ \\
Odak ve doğrultman doğrusunu tanımayı sağlıyor. & 1 & \\
Asal ve yedek ekseni tanımayı sağlıyor & \\
\hline
\end{tabular}

Tablo 10' a bakıldığında genellemelere varma hakkında ders öğretmeni ve öğrencilerin daha çok, elips, hiperbol ve parabolü kavramsal olarak anlayabilme üzerinde durdukları belirlenmiştir. Öğrencilerden C15, elips, hiperbol ve parabolü tanıyabildiğini şu sözlerle açılamıştır;

"Konik oluşturma aklımda kaldı. Bir doğrultman doğru ve odak noktaları verildiğinde artık kendim çizebilirim bunu. Koordinat düzleminde kendim bunu gerçekleştirebilirim. Ama önceden bunu mesela görmemiş olsaydım nasıl oluştuğunu yapamazdım."

Ders öğretmeni ise öğrencilerin koniklere ait temel terimleri öğrendiklerini ve ilerleyen yıllarda bunu kullanmaları gerektiğinde hatırlayabileceklerini;

"Koniklere ait odak ve doğrultman doğrusunu nasıl belirleyebileceklerini biliyorlar. Oradaki değiş̧kenlerin birbirine bağlı olarak değiş̧imini ne şekilde olduğunu kendilerinin görmelerini istedik. Ĕ̆ger konikler üniversite hayatında tekrar lazım olacak olursa bu bilgileri tekrar çă̆ırmaları daha çabuk olacaktır, daha net olacaktır, daha kolay olacaktır."

ifadeleriyle dile getirmiştir. 


\section{Sonuç ve Tartışma}

“Konikler ünitesinin BDİDÖ ortamında öğretiminden elde edilen gözlem sonuçları; öğrenme ortamı, öğretmen davranışları ve takım davranışları alt kategorileri altında ele alınmıştır. Buna göre öğrenme ortamında, ünitenin tüm kazanımlarının öğretiminde ilk kazanımdan itibaren işbirlikli takımların davranışları BDİDÖ ortamına uygun olarak gerçekleştirdiği, bilgisayar ve etkileşimli tahtanın BDİDÖ ortamında etkin kullanıldığı elde edilen gözlem sonucudur.

Öğretmen davranışları incelendiğinde, ünitenin tüm kazanımlarının öğretiminde ilk kazanımdan itibaren öğretmen davranışlarının BDİDÖ ortamına uygun olarak gerçekleştiği elde edilen gözlem sonucudur.

Takım davranışları her kazanım için ayrı ayrı incelendiğinde; konik ve koniğin temel elemanlarının öğretiminde takımların verilen bazı davranışları yüzeysel olarak gerçekleştirdikleri, bazı davranışları ise BDIDÖ ortamına uygun olarak gerçekleştirmeye yakın oldukları sonucu elde edilmiştir. Materyalleri kullanarak genellemelere ulaşmayı BDIDÖ ortamına uygun olarak gerçekleştirmeye yakın oldukları, genellemelerin cebirsel ifadelerini tanımlamayı ise yüzeysel olarak gerçekleştirdikleri belirlenmiştir. Buna göre konik ve koniğin temel elemanlarının öğretiminde BDİDÖ ye uygun olarak gerçekleştirmeye yakın davrandıkları söylenebilir. Elips, hiperbol, parabol ve standart denklemlerinin öğretiminde takımların verilen davranışların tamamını BDIDÖ ortamına uygun olarak gerçekleştirdikleri ya da gerçekleştirmeye çok yakın oldukları sonucu elde edilmiştir. Buna göre takımların davranışları BDIDDÖ ye uygun olarak gerçekleştirmeye yakın davrandıkları söylenebilir. Ayrıca takımların bütün davranışları BDİDÖ ye uygun olarak gerçekleştirme düzeyleri bir önceki kazanıma göre arttığı veya aynı olduğu belirlenmiştir.

Konikler ünitesinin BDİDÖ ortamında öğretiminden elde edilen gözlem sonuçları genel olarak değerlendirildiğinde; öğrenme ortamının ve ders öğretmeninin davranışlarının ilk dersten itibaren BDİDÖ ortamına uygun olduğu ve takımları oluşturan öğrencilerin davranışlarının BDİDÖ ortamına uygun olacak şekilde geliştiği elde edilen sonuçlar arasındadır.

BDİDÖ ortamında koniklerin öğretimine ilişkin öğrenci ve ders öğretmeninin görüşleri; BDİDÖ ortamında konikleri öğrenme, dinamik materyal, çalışma yaprakları ve işbirlikli çalışma, öğrenmeyi etkileyen faktörler ve genellemelere varma alt kategorileri altında incelenmiştir. Öğrencilerin ve ders öğretmeninin BDIDÖ ortamında konikleri öğrenme hakkında en fazla; kalıcı ve kolay öğrenmeyi sağladığını ve derse olan ilgiyi artırdığını düşündükleri görülmüştür. Kutluca ve Birgin (2007) doğru denklemi konusunda hazırladıkları materyal ile ilgili olarak öğretmen adaylarının kullanımının kolay, açık ve anlaşılır olduğunu, öğrenme isteğini arttırdığını ve konuyu somutlaştırıp anlamayı kolaylaştırdığını düşündüklerini belirlemişlerdir. Elde edilen bu sonuç bu araştırmanın sonucuyla benzerlik göstermektedir.

Öğretmen ve öğrencilerin dinamik materyal ve çalışma yaprakları hakkında daha çok, değişkenlere farklı değerler verebilme, konuyu görselleştirme ve değerler arasındaki farkları ayırt etmeyi sağlayabilmesi üzerinde durdukları belirlenirken; işbirlikli çalışma hakkında en fazla birlikte öğrenmeyi sağladığı üzerinde durdukları tespit edilmiştir. Takači, Stankov, ve Milanovic (2015) GeoGebra'nın kullanıldığı BDïÖ'nin uygulandığı öğrencilerin, fonksiyonların grafiklerinin çizilmesi konusunda aynı elektronik sayfa üzerinde fonksiyonun birinci ve ikinci türevlerinin grafiklerini de görebildiklerini ve daha iyi karşılaştırma yapabildiklerini belirtirken bu öğrencilerin işbirliği ve iletişim halinde olduklarını ifade etmişlerdir. Wei ve Ismail (2010) Geogebra'nın kullanıldığı BDİÖ ortamında kız ve erkekten oluşan ikili işbirlikli grupların uygulamalar boyunca aktif katılımı sağladıklarını, bununla birlikte birbirleriyle olan etkileşimlerini sınırladıklarını belirlemiştir. Bu yönüyle elde edilen sonuçlar bu araştırmadan elde edilen sonuçla benzerlik göstermektedir. Ayrıca bu sonuç, Aktümen ve Kaçar (2003)' in çalışmalarında elde ettiği sekizinci sınıf öğrencilerinin bilgisayar destekli öğretim hakkında belirttikleri görüşlerle benzerlik göstermektedir. Yılmaz, Ertem ve Güven'in (2010) dinamik geometri yazılımı Cabri'nin öğrencilerin farklı durumları gözlemlemelerini ve genellemelere ulaşabilmeyi sağladığını belirledikleri araştırmanın bulgusuyla benzerlik göstermektedir. Zengin ve Tatar'ın (2014) GeoGebra'nın görselleştirme, konuyu yaparak anlama ve yorumlama sağladığını elde ettikleri araştırmanın sonucuyla paralellik göstermektedir. Bu araştırmanın sonucu olan işbirlikli öğrenmenin birlikte öğrenmeyi sağladığı sonucu Granberga ve Olsson (2015)'nın GeoGebra'nın kullanıldığı işbirlikli öğrenme ortamında öğrencilerin problem çözmede çıkarımsal düşünme becerilerinin işbirlikli öğrenmeleri yoluyla arttığını buldukları araştırma sonucuyla benzerlik göstermektedir. 
Öğrenciler BDIDÖ ortamında konikleri öğrenmeyi etkileyen faktörler olarak daha çok, bireysel veya takım halinde materyalleri uygulayabilmek olduğunu belirtirmişlerdir. Ders öğretmeninin ise konikleri öğrenmeyi etkileyen faktörler olarak değişkenlerin farklı değerlerini görebilmeyi, öğrencilerin derste aktif rol oynamasını, izleme testlerinin yapılmasını, genellemelere tartışarak varabilmeyi ve doğruluğunu gözlemleyebilmeyi belirlediği görülmüştür. Genellemelere varma hakkında ise ders öğretmeni ve öğrencilerin daha çok elips, hiperbol ve parabolü kavramsal olarak anlayabilme üzerinde durdukları görülmüştür. Kabaca, Çontay ve İymen, (2011) lise öğrencilerinin bilgisayar üzerinde GeoGebra yazılımı ile grup ya da bireysel olarak çalışarak doğrultman ve odak noktasının parametrelerinden yola çıkıp, parabol denkleminin katsayılarını elde ettiklerini tespit etmişlerdir. Öğrencilerin parabol kavramının geometrik temsili ile cebirsel temsili arasındaki çift yönlü ilişkiyi fark edebilmek için hazır komut kullanmadan, parabol eğrisinin geometrik tanımından yola çıktıklarını belirtmişlerdir. Arnold (2006) ise GeoGebra' dan faydalanarak parabol eğrisinin noktalar kümesini inşa etmeden yazılımda bulunan hazır komutu kullanarak görselleştirmiştir. Belirtilen araştırmaların sonuçları ile bu araştırmanın sonuçları benzerlik gösterdiği ortaya çıkmaktadır.

Yapılan bu çalışmada elde edilen gözlem ve sonuçlara dayanılarak çeşitli önerilerde bulunulacak olursa, hazırlanacak BDİDÖ ortamında takımların çalışma masalarının yerlerinin birbirinden ayrı olması ve sınıf ortamında her takımın kendi aralarında tartışma yapabilecekleri çalışma ortamı sağlanabilmelidir. Uygulamalar boyunca, her takımın ders haricinde bilgisayar üzerinde birlikte çalışma yapması mümkün olmadığı gözlenmiştir. Bu konuda liselerdeki bilgisayar laboratuvarlarında öğrencilerin uygun zamanlarda çalışma yapabilmeleri teşvik edilip, sağlanabilir. Bir diğer durum ise, BDİDÖ ortamında öğretmen ve öğrencilerin bu uygulamayı gerçekleştirmeleri için bilgisayar veya tabletlerle teknolojik donanımın sağlandığı ve takımların çalışmalarını yürütebileceği uygun genişlikte olan yeni teknoloji destekli matematik laboratuvarlarının kurulmasının önemli olduğudur.

\section{Kaynakça}

Açıkgöz, K. Ü. (1992). İşbirlikli öğrenme, kuram, araştırma, uygulama. Malatya: Uğurel Matbaası.

Açıkgöz, K. Ü. (2003). Aktifö̆grenme (5. Baskı). İzmir: Eğitim Dünyası Yayınları.

Aktümen, M., \& Kaçar, A. (2008). Bilgisayar cebiri sistemlerinin matematiğe yönelik tutuma etkisi. Hacettepe Üniversitesi Ĕ̆gitim Fakültesi Dergisi, 35, 13-26.

Arnseth, H. C., \& Ludvigsen, S. (2006). Approaching institutional contexts: Systemic versus dialogic research in CSCL. Computer Supported Collaborative Learning, 1, 167-185. doi: 10.1007/s11412-006-8874-3

Arnold, S. (2006).http://www.compasstech.com. au/ARNOLD/geogebra/parabola. html, 11/02/2015 tarihinde indirilmiştir.

Beecher, J. A.,Penna, J. A., \& Bittinger, M. L. (2007). Algebra and trigonometry. (4th ed.). Boston: Pearson.

Boyd, C. J., Cummins, J., Malloy C. E., Carter, J. A., \& Flores, A. (2008). California geometry. Columbus: McGraw-Hill Companies.

Boyer, C. B. (1956). History of analytic geometry. New York: Scripta Mathematica.

Buder, J. (2011). Group awareness tools for learning: Current and future directions. Computers in Human Behaviour, 27, $1114-1117$.

Burger., E. B., Chard., D. J., Hall., E. J., Kennedy., P. A., Leinwand., S. J., Renfro., F. L., Roby., T. W., Seymour., D. G., \& Waits., B. K. (2008). California geometry. New York: A Horcoun Education Company.

Çelik, Ö. (2013). Ortaöğretim Geometri 11 ders kitabı. Ankara: Bilgetürk Eğitim Yayınları.

Ching Sing, C. Wei Ying, L. Hyo-Jeong S., \& Horn Mun, C. (2011). Advancing collaborative learning with ICT: Conception, cases and design. (First ed.). Singapore: Ministry of Education.

Creswell, J. W. (2011). Educational research: Planning, conducting, and evaluating quantitative and qualitative research (4th ed.). Baston: Pearson.

Granberga, C., \& Olsson, J. (2015) ICT-supported problem solving and collaborative creative reasoning: Exploring linear functions using Dynamic mathematics software. Journal of Mathematical Behavior, 37, 48-62

Güven, B., \& Karataş, İ. (2009). Dinamik geometri yazılımı Cabri' nin ilköğretim matematik öğretmen adaylarının geometrik yer problemlerindeki başarılarına etkisi. Ankara Üniversitesi Ĕ̆itim Bilimleri Fakültesi Dergisi, 42(1), 1-31.

Hungerford, T. W. \& Shaw, D. J. (2009). Contemporary precalculus: A Graphing approach. (5th ed.). Belmont: Thomson Higher Education.

Ilgar, R., \& Babacan, Ş. (2012). İşbirlikli öğretim yöntemi destekli çoklu zeka kuramının coğrafya konularının öğretiminde başarıya etkisi. Hacettepe Üniversitesi Ĕ̆itim Fakültesi Dergisi, 42, 212-224.

Kabaca, T., Çontay, E. G., \& İymen, E. (2011). Dinamik matematik yazılımı ile geometrik temsilden cebirsel temsile: Parabol kavramı. Pamukkale Üniversitesi Ĕ̆itim Fakültesi Dergisi, 30(2), 101-110.

Kutluca, T., \& Birgin, O. (2007). Doğru denklemi konusunda geliştirilen bilgisayar destekli öğretim materyali hakkında matematik öğretmeni adaylarının görüşlerinin değerlendirilmesi. Gazi Eğitim Fakültesi Dergisi, 27(2), 81-97.

Larson, R., Boswell, L., Kanold, T. D., \& Stiff, L. (2004). Algebra 1.Evanston: McDougalLittell.

Lee, E. Y. C., Chan, C. K. K., \& Aalst, J. V. (2006).Students assessing their own collaborative knowledge building. Computer Supported Collaborative Learning,1, 57-87. doi: 10.1007/s11412-006-6844-4 
Lial, M. L., Hornsby, J., \& McGinnis, T. (2012). Beginning and intermediate algebra (5th ed.). Boston: Pearson Education.

Lipponen L., Rahikainen M., Lallimo J., \& Hakkarainen K. (2003) Patterns of participation and discourse in elementary students' computer-supported collaborative learning. Learning and Instruction 13, 487-509.

MEB, (2010a). Ortaöğretim Geometri Dersi 9-10. Sınıflar Öğretim Programı, Ankara.

MEB, (2010b). Ortaöğretim Geometri Dersi 11. Sınıf Öğretim Programı, Ankara.

MEB, (2013a). Ortaöğretim Matematik Dersi (9, 10, 11 ve 12. Sınıflar) Öğretim Programı, Ankara.

MEB, (2013b). Ortaöğretim geometri 10. Ankara: MEB Komisyon.

McMillan, J. H., \& Schumacher, S. (2010). Research in education: Evidence-basedinquiry (7th ed.). Boston: Pearson.

Slavin, R. E. (1980). Cooperative Learning. Reviev of EducationalResearch,50 (2), 315-342.

Slavin, R. E. (1990). Cooperativelearning: Theory, research and practice. Englewood Cliff, NJ: Prentice- Hall.

Slavin, R. E. (1994). Studentteams-achievement divisions. In S. Sharan (Eds.), Handbook of cooperative learning methods(pp. 3-19). London: Westport, Connecticut.

Stahl, G.,Koschmann, T., \&Suthers, D. (2006). Computer-supported collaborative learning: An historical perspective. In R. K. Sawyer (Ed.), Cambridge handbook of thelearning sciences(pp. 409-426). [Online] http://GerryStahl.net/cscl/CSCL_English.pdf, 22/02/2015 tarihinde indirilmiştir.

Sullivan, M. (2008). Algebra and Trigonometry.(8th. ed.). USA: Pearson Education.

Takači D., Stankov G., \& Milanovic I. (2015). Efficiency of learning environment using GeoGebra when calculus contents are learned in collaborative groups, Computers and Education. doi: 10.1016/j.compedu.2014.12.002

Timmons, D. L., Johnson, C. W., \& McCook, S. M. (2010). Fundamentals of algebraic modeling: An introduction to mathematical modeling with algebra and statistics (5th. ed.). Belmont: Brooks/Cole, Cengage Learning

Wei, C. S., \& Ismail, Z. (2010) Peer interactions in computer-supported collaborative learning using dynamic mathematics software.Procedia Social and Behavioral Sciences 8 (2010) 600-608. International Conference on Mathematics Education Research 2010 (ICMER 2010)

Yıldırım, A.,\& Şimşek, H. (2008). Sosyal bilimlerde nitel araştırma yöntemleri (7. Baskı).Ankara: Seçkin Yayıncllık.

Yılmaz, G. K., Ertem , E., \& Güven, B. (2010) Dinamik Geometri Yazılımı Cabri'nin 11.Sınıf Öğrencilerinin Trigonometri Konusundaki Öğrenmelerine Etkisi. Turkish Journal of Computer and Mathematics Education, 1(2), 200-216.

Young, A. E. (1909). On the teaching of analytic geometry. The American Mathematical Monthly, 16(12), 205-212.

Zengin, Y., \& Tatar, E. (2014). Türev uygulamaları konusunun öğretiminde GeoGebra yazılımının kullanımı. Kastamonu Ĕ̆itim Dergisi, $22(3), 1209-1228$

[GeoGebra resmi sitesi]. (www.geogebra.org)

[Koniklerin inşasına yer veren videolar].wwww.youtube.com15/03/2014tarihinde faydalanılmıştır.

[Matematik eğitimi sitesi]. www.mathopenref.com10/02/2014 tarihinde faydalanılmıștır.

[Matematik eğitimi sitesi].www.mathsisfun.com/geometry 15/02/2014 tarihinde faydalanılmıștır. 


\section{Ek-1}

\section{MÜLAKAT SORULARI}

1. …....................kazanımını BDİÖ ortamında öğrenirken nasıl bir yol izlediniz?

a) Çalışma yaprakları ve dinamik materyalleri nasıl kullandınız?

b) Konuyu öğrenirken neler (hangi kavramlar) dikkatinizi çekti?

2. Bilgisayar destekli işbirlikli çalışmalarda neler gözlemlediniz?

a) Takım olarak genellemelere nasıl ulaştınız?

b) Öğrenmekte zorluk yaşadığınız durumlar var mıydı?

_Nasıl bir çözüm yolu geliştirdiniz?

3. Belirtmek istediğiniz başka görüş ve öneri var mı? Teşekkür ederim.

Ek-2

\section{MÜLAKAT SORULARI}

1. .....................kazanımını BDİDÖ ortamında öğretirken nasıl bir yol izlediniz?

a) Çalışma yaprakları ve dinamik materyalleri nasıl kullandınız?

b) Konunun öğretiminde neler dikkatinizi çekti?

c) Konunun öğretiminde öğretmenin anlatması gereken kavramlar nelerdir?

2. Öğrencilerin bilgisayar destekli işbirlikli çalışmalarında neler gözlemlediniz?

a) Takımlar genellemelere ulaşabilmek için neler yaptılar?

b) Öğrencilerin öğrenmekte zorluk yaşadıkları durumlar var mıydı?

_Takımlar nasıl bir çözüm yolu geliştirdi?

3. Belirtmek istediğiniz başka görüş ve öneri var mı? Teşekkür ederim.

Ek-3

\section{MÜLAKAT SORULARI}

1. ……………....ünitesini BDIDÖ ortamında öğrenme ile ilgili neler düşünüyorsunuz?

2. Uygulamalar sırasında gözlemleriniz ve değerlendirmeleriniz nelerdir?

a) Dinamik materyaller hakkında neler düşünüyorsunuz?

b) Çalışma yaprakları hakkında neler düşünüyorsunuz?

c) Takım halinde işbirlikli olarak öğrenme ile ilgili ne düşünüyorsunuz?

3. BDİDÖ ortamı üniteyi öğrenmenizi nasıl etkiledi?

4. BDİÖ ortamında genellemelere varmanız hakkında neler düşünüyorsunuz?

5. Dinamik ortamda işbirlikli çalışmak size hangi sosyal becerileri sağladı?

6. Belirtmek istediğiniz başka görüş ve öneri var mı? Teşekkür ederim.

Ek-4

\section{MÜLAKAT SORULARI}

1. Öğrencilerin BDİDÖ yoluyla .............ünitesini öğrenmeleri hakkında neler düşünüyorsunuz?

2. Uygulamalar sırasında gözlemleriniz ve değerlendirmeleriniz nelerdir?

a) Dinamik materyallerin kullanımı hakkında neler düşünüyorsunuz?

b) Çalışma yapraklarının kullanımı hakkında neler düşünüyorsunuz?

c) Takımların işbirlikli çalışması hakkında neler düşünüyorsunuz?

d) İzleme testlerinin uygulanması hakkında neler düşünüyorsunuz?

3. BDİÖ ortamında öğrencilerin öğrenmelerini etkileyen faktörler neler oldu?

4. Öğrencilerin BDİDÖ ortamında genellemelere varmaları hakkında neler düşünüyorsunuz?

5. Takımların dinamik ortamda işbirlikli çalışmaları hangi sosyal becerileri sağladı?

6. Belirtmek istediğiniz başka görüş ve öneri var mı? Teşekkür ederim.

\section{Ek-5}

\section{MÜLAKAT SORULARI}

1.BDIDÖ ortamında .............ünitesini takımla birlikte öğrenirken nasıl bir yol izlediniz (strateji geliştirdiniz)?

a) Çalışma yapraklarını ve dinamik materyalleri nasıl kullandınız?

b) Konuyu öğrenirken neler (hangi kavramlar) dikkatinizi çekti?

c) Takım olarak genellemelere nasıl ulaştınız?

d) Takım olarak karşılaştığınız problemleri çözebilmek için nasıl bir yol izlediniz?

2. ............ünitesini bilgisayar destekli işbirlikli dinamik öğrenmenizi nasıl değerlendiriyorsunuz?

a) Dinamik materyaller hakkında neler düşünüyorsunuz?

b) Çalışma yaprakları hakkında neler düşünüyorsunuz?

c) Takım halinde işbirlikli olarak öğrenme ile ilgili ne düşünüyorsunuz?

3. BDİDÖ ortamında genellemelere varmanız hakkında neler düşünüyorsunuz?

4. Dinamik ortamda işbirlikli çalışmak size hangi sosyal becerileri sağladı?

5. Belirtmek istediğiniz başka görüş ve öneri var mı? Teşekkür ederim. 